THE HAKLUYT SOCIETY ANNUAL LECTURE 2013

\title{
'A JUST AND HONOURABLE COMMERCE': ABOLITIONIST EXPERIMENTATION IN SIERRA LEONE IN THE LATE EIGHTEENTH AND EARLY NINETEENTH CENTURIES ${ }^{1}$
}

\author{
Suzanne Schwarz \\ Delivered at the Annual General Meeting of the Hakluyt Society \\ 19 June 2013
}

I

In the late eighteenth and early nineteenth centuries, a small strip of territory on the Sierra Leone peninsula was used as an experimental site by leading abolitionist campaigners to test out methods of eradicating the Atlantic slave trade. ${ }^{2}$ From its foundation in 1787, the 'infant colony' ${ }^{3}$ at Sierra Leone played a pivotal role in the campaign to end the slave trade and its growth and development took place against a backdrop of growing European interest in travel and exploration in Africa. ${ }^{4}$ This small-scale intervention subsequently had wider repercussions for British involvement in West Africa, as 'its annexation as a British Crown Colony in 1808 effectively represented the beginning of the creation of the British empire in Tropical Africa'. 5 The settlement, initially known as the 'Province of Freedom', was located on a stretch of the upper

\footnotetext{
${ }^{1}$ I would like to thank Roy Bridges, Nicholas Evans, Magbaily Fyle, Robin Law, Paul Lovejoy, Bruce Mouser and Silke Strickrodt for their valuable comments and suggestions. I am very grateful to a colleague for permission to reproduce the 'Plan of Sierra Leone and the Parts Adjacent, MDCCXCIV', which is in a private collection. I also thank Henry Lovejoy for permission to use his map of the upper Guinea coast and the Wisbech and Fenland Museum for permission to reproduce an image in its collection. I am grateful to the National Maritime Museum, Greenwich for permission to reproduce most of the images in this paper. The research on which this paper is based was supported by funding from The Leverhulme Trust and the Society for Nautical Research. This paper is dedicated to the memory of Paul Hair, a former President of the Hakluyt Society, who first sparked my interest in the history of Sierra Leone. For the quotation in the title, see note 9 below.

${ }^{2}$ Initially, the colony occupied only the northern tip of the peninsula. By 1820 , it was 'apparently now taken for granted that the Colony coincided with the area of the (physical) Peninsula'. Different meanings have been attached to the use of the term 'Sierra Leone' between the fifteenth and the nineteenth centuries. P. E. H. Hair, 'The Spelling and Connotation of the Toponym "Sierra Leone" since 1461', Sierra Leone Studies, New Series, 18, January 1966, pp. 43-58.

${ }^{3}$ In the Company report of 1794 , the directors described how the colony was developing from its 'earlier infancy' and making 'gradual advances towards maturity'. Substance of the Report Delivered by the Court of Directors of the Sierra Leone Company to the General Court of Proprietors on Thursday the 27th March, 1794, London, 1794, pp. 20, 35, 127.

${ }^{4}$ Philip D. Curtin, The Image of Africa. British Ideas and Action, 1780-1850, London, 1965, pp. v-vii, 6-10, 14-27.

${ }^{5}$ Robin Law, 'Before 1787: The First 325 years of Afro-European Interactions in Sierra Leone', Keynote Lecture at 'Sierra Leone Past and Present', International Conference, Freetown, April 2012.
} 


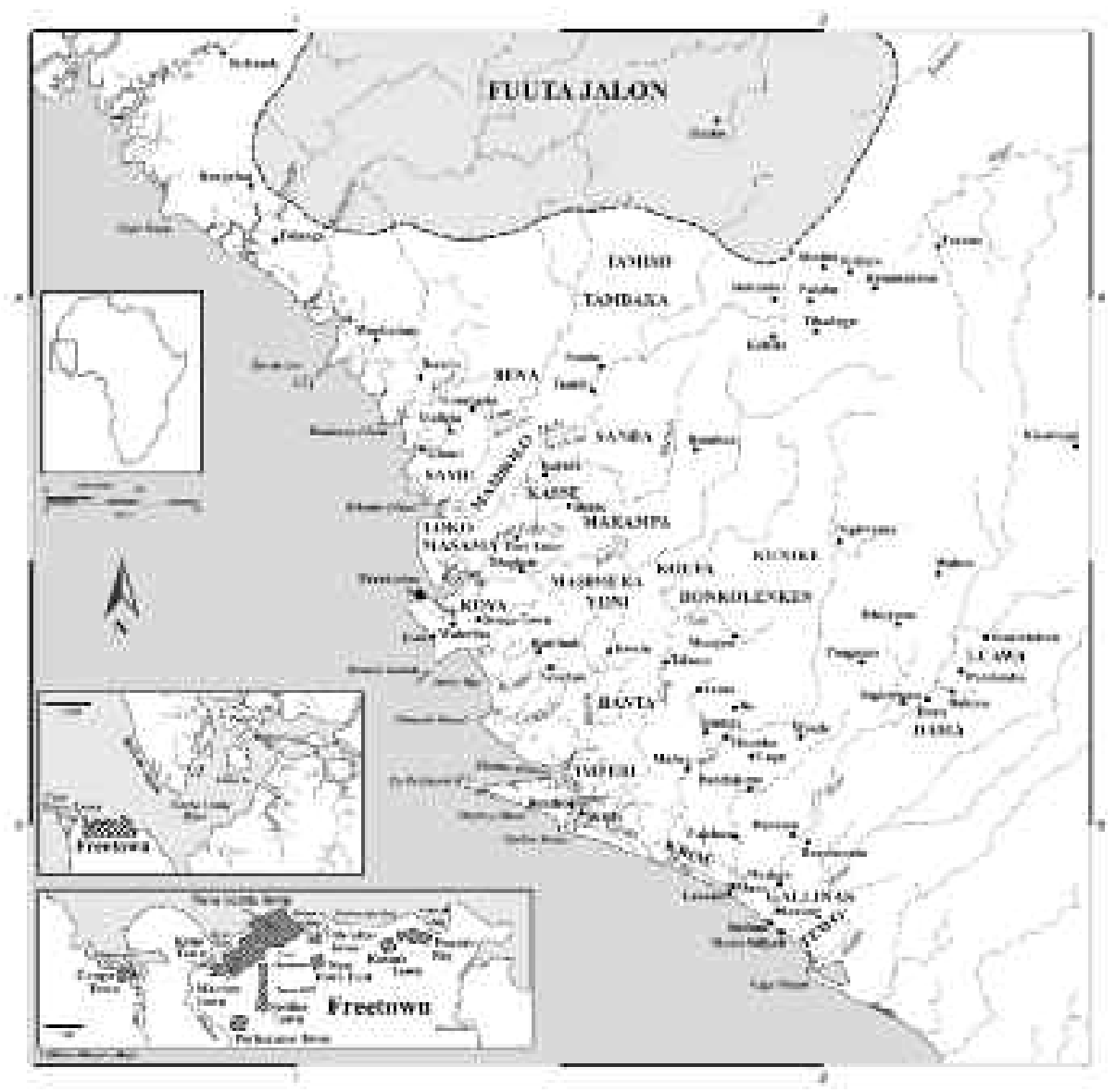

Figure 1. Map of Upper Guinea Coast, c. 1820. Reproduced courtesy of Henry Lovejoy, African Diaspora Maps, Ltd.

Guinea coast (Figures 1 and 2) that had rapidly expanded its role in supplying enslaved Africans to European and American slave traders in the mid to late eighteenth century. ${ }^{6}$ The colony was located in an area that had been known to Portuguese traders since the late fifteenth century. Paul Hair notes how:

the first map to show the Sierra Leone peninsula, though produced in Italy, used the original Portuguese form, "Sera Lyoa", and the only variants which appeared on fifteenth-century maps were Serra/Sera Lyoa/Lioa.

${ }^{6}$ Paul E. Lovejoy and David Richardson, 'African Agency and the Liverpool Slave Trade', in David Richardson, Suzanne Schwarz and Anthony Tibbles, eds, Liverpool and Transatlantic Slavery, Liverpool, 2007, pp. 44-7.

${ }^{7}$ Hair, 'Spelling and Connotation of the Toponym "Sierra Leone" since 1461', p. 43. Hair also 


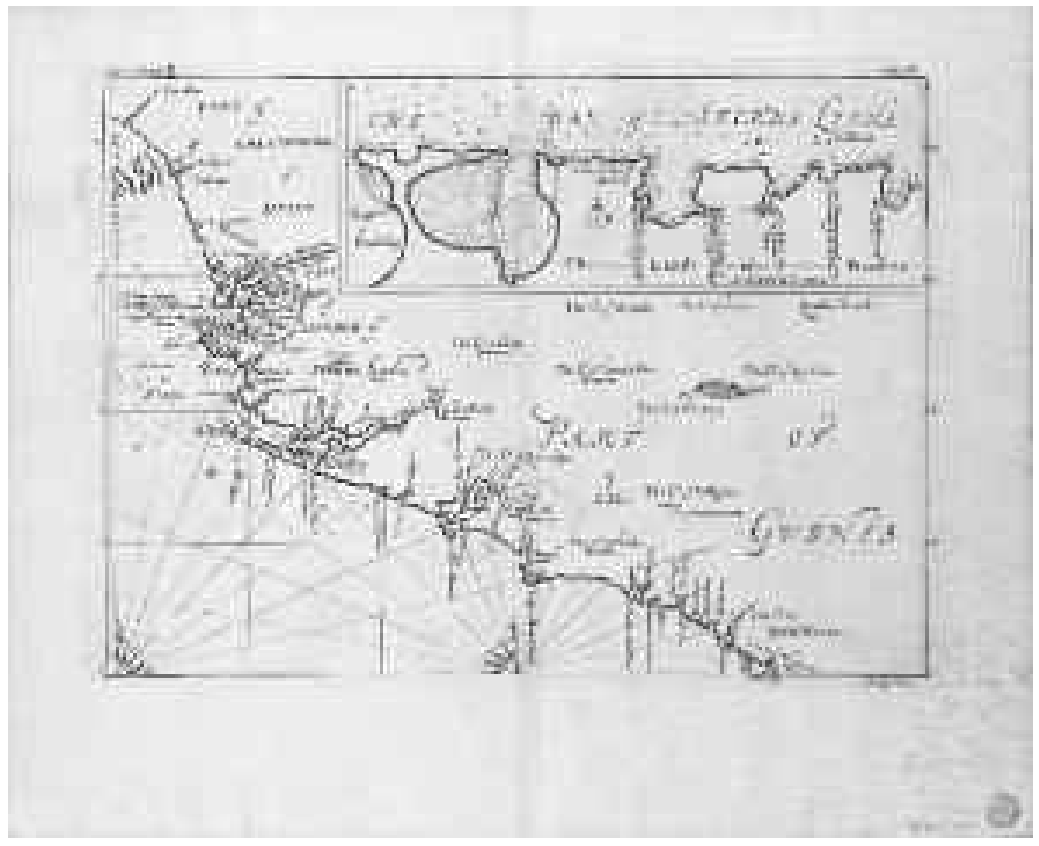

Figure 2. Chart of Part of the Coast of Sierra Leone and Liberia from Los Islands (Guinea) to River Cess (Liberia), J. Kip, 1732. FO418 @ National Maritime Museum, Greenwich, London

By the time the abolitionists established their experimental colony in Sierra Leone, there had been over three centuries of Afro-European interactions on the upper Guinea coast based on trade in slaves, provisions and gold. ${ }^{8}$ Viewed narrowly from the British abolitionist perspective, Sierra Leone had a new role to play in the late eighteenth century as a model of economic and social reform in West Africa.

In the two decades preceding British abolition of the trade in 1807 , Sierra Leone emerged as an important focus for debate on methods of halting the traffic in enslaved Africans, attacking the system of plantation slavery in the Americas and promoting an alternative 'legitimate' form of commerce.

drew attention to how 'the Sierra Leone peninsula was first encountered by Europeans in 1460 or 1461, and thereafter, for two centuries, the European visitors to the peninsula, to its flanking estuary, and to long stretches of the coast to north and south, were chiefly Portuguese, most of them traders, with a few of them making at least temporary homes on the banks of the rivers': P. E. H. Hair, 'Christian influences in Sierra Leone before 1787', Journal of Religion in Africa, xxvi, 1, 1996, pp. 112, (p. 1). See also, Walter Rodney, A History of the Upper Guinea Coast, 1545-1800, Oxford, 1970, pp. viii, 1 .

${ }^{8}$ Law, 'Before 1787: The First 325 years of Afro-European Interactions in Sierra Leone'. 
Experimentation by the Sierra Leone Company, which administered the colony prior to its annexation in 1808, focused on the development of 'honourable' or ethical trade in agricultural produce, ${ }^{9}$ although the abolitionists' frequent interlinking of moral, religious and economic arguments was reflected in the development of policies promoting commerce, civilization and Christianity in West Africa. ${ }^{10}$

Methods of abolitionist intervention in Sierra Leone were developed in tandem with campaigning strategies deployed in Britain; evidence collected on the ground in West Africa by Zachary Macaulay, who served as acting governor and governor at different intervals in the 1790s, was relayed to Henry Thornton, the Company Chairman, in London and was used to support arguments presented in pamphlet literature and the parliamentary arena. ${ }^{11}$ Negative reports of Company affairs which filtered back to London were frequently used by antiabolitionists to attack the Company and this, combined with the haemorrhaging of shareholder capital by the turn of the nineteenth century, meant that Sierra Leone often had to be defended by its abolitionist promoters as a useful and worthwhile experiment which would reshape African society and economy. After the passage of the Act for the Abolition of the Slave Trade in 1807, Sierra Leone became central to Britain's new global campaign to abolish the trade and was used to implement military and legal strategies designed to halt the outward flow of enslaved Africans in ships of various nations (Plate 1). In a context of on-going maritime warfare with France, the number of Royal Navy ships deployed in the immediate aftermath of abolition was small but the policy of forcibly relocating recaptive or liberated Africans from intercepted slave ships to designated areas around the Atlantic world was first implemented at Freetown in $1808 .^{12}$

\footnotetext{
9 The phrase 'a just and honourable commerce' was used in the directors' report to shareholders in 1791. In their report of 1794 , the directors referred to the development of an 'honest, innocent, and peaceful commerce'. Postscript to the Report of the Court of Directors of the Sierra Leone Company to the General Court Held at London on Wednesday $19^{\text {th }}$ of October, 1791, London, 1791, p. 4; Substance of the Report, 1794, p. 117.

${ }^{10}$ Stanley L. Engerman and David Eltis, 'Economic Aspects of the Abolition Debate', in Christine Bolt and Seymour Drescher, eds, Anti-Slavery, Religion and Reform: Essays in Memory of Roger Anstey, Folkestone, 1980, pp. 272-4, 281-3; Christopher Leslie Brown, 'The Origins of "Legitimate Commerce"', in Robin Law, Suzanne Schwarz and Silke Strickrodt, eds, Commercial Agriculture, the Slave Trade \& Slavery in Atlantic Africa, Woodbridge, 2013, pp. 138-40.

${ }^{11}$ The Company report of 1794 noted that 'Regular minutes of council were kept from this period, and also a journal of every material transaction in the colony, copies of which were sent to England from time to time'. Substance of the Report, 1794, p. 16.

${ }_{12}^{12}$ David Eltis and David Richardson, Atlas of the Transatlantic Slave Trade, New Haven/London, 2010, pp. 271-89; Tara Helfman, 'The Court of Vice Admiralty at Sierra Leone and the Abolition of the West African Slave Trade', The Yale Law Journal, 115, 2006, pp. 1122-56; A. W. H. Pearsall, 'Sierra Leone and the Suppression of the Slave Trade', Sierra Leone Studies, New Series, 12, December 1959, pp. 211-29. Saunders indicates that, 'between December 1808 and December 1816 twenty-seven ships were intercepted and taken into Table Bay or Simon's Bay': Christopher Saunders, 'Liberated Africans in Cape Colony in the First Half of the Nineteenth Century', The International Journal of African Historical Studies, 18, 2, 1985, pp. 223-39 (223-4).
} 
An innovative feature of late eighteenth-century experimentation in Sierra Leone, which has often been marginalized in the historiography of abolition, is the way in which the promoters of the Sierra Leone Company considered that the long-term solution to stemming the traffic in enslaved Africans depended not just on legislative reform to prohibit slave exports in British ships but on persuading African merchants to abandon slave trading in favour of a commerce based on the natural productions of the African soil. Clear precursors of mid nineteenth-century policies towards West Africa can be traced in the Company's attempts to reach agreements with African leaders to turn away from slave trading in favour of commodities other than slaves. On 3 March 1794 a meeting took place between James Watt, an employee of the Sierra Leone Company, and Almamy Sadu, ruler of Fuuta Jalon, who lived at Timbo, capital of the Fula state. Watt, who had been instructed to make 'discoveries in the interior parts of Africa' and to 'open trade into Timbo', ${ }^{13}$ explained to the Almamy that the Company wanted to open a new trade in rice, cattle and ivory, but they would 'not deal in slaves, because God said it was wrong. ${ }^{14}$ As Watt had spent six weeks travelling from Freetown to Timbo for this opportunity to persuade Muslim slave traders to support Company plans to develop a 'fair trade' on the coast of West Africa, he tried to secure regular audiences with the Almamy to explain the Company's plan of trade in detail. ${ }^{15}$ Almamy Sadu did not accept Company ideas passively, and challenged Watt by asking 'how it was that every white person that comes to Africa should want slaves more than any thing else, \& that we could not buy them'. ${ }^{16}$ Watt, a former plantation overseer in the West Indies, received a similarly negative reaction six days later when he attempted to persuade another headman of Timbo that the Fula should set aside slave trading in favour of planting more cotton and learning to plough their ground with cattle. ${ }^{17}$

By sending Watt on an expedition to this area, hitherto unexplored by Europeans, officials of the Sierra Leone Company based at Freetown demonstrated their awareness of the central importance of Fuuta Jalon to the supply of slaves to ports on the upper Guinea coast. ${ }^{18}$ The underlying logic for this and

${ }^{13}$ The National Archives [hereafter TNA], CO 270/2, Sierra Leone, Minutes of Governor and Council, p. 131.

${ }^{14}$ Bruce L. Mouser, ed., Journal of James Watt. Expedition to Timbo Capital of the Fula Empire in 1794, Madison, WI, 1994, pp. 31-3.

15 The term 'fair trade' was used by Watt on at least three occasions. Although the term is the same as that in modern-day usage, the meaning differs in a number of ways. Mouser, Journal of James Watt, pp. 38, 62, 74 .

${ }^{16}$ Ibid., p. 33.

${ }^{17}$ Ibid., pp. xv, 33, 44. The Company report of 1794 indicates that Watt was 'formerly manager of the estate of George Rose, Esq. M.P. in Dominica', Substance of the Report, 1794, p. 134.

${ }^{18}$ Rodney, History of the Upper Guinea Coast, pp. 223-70; Bruce L. Mouser, 'Continuing British Interest in Coastal Guinea-Conakry and Fuuta Jaloo Highlands (1750 to 1850)', Cahiers d'Études africaines, XLIII(4), 172, 2003, pp. 761-90 (762-70). 
other land and sea journeys undertaken by Company employees in the $1790 \mathrm{~s}$ was to attack the slave trade at its source, thereby stemming the outward flow of Africans into the Atlantic trade (Plate 2). As such, Watt's venture needs to be seen as part of a wider attempt to develop an African dimension to abolition. At a time when campaigning initiatives in Britain focused principally on securing abolition through Parliament, promoters of the Sierra Leone Company, the chartered trading company incorporated in 1791, sought to extinguish this 'savage and disgraceful traffic' by working within Africa to develop policies of commerce, civilization and Christianity. ${ }^{19}$ Watt's expedition coincided with attempts by the Association for Promoting the Discovery of the Interior Parts of Africa to reach the African interior in the 1790s. Company directors were aware of the interests of the African Association, and in their report on Watt's expedition noted how:

Diligent inquiry was made both at Laby and Teembo, concerning the route to Tombuctoo, a town in the heart of Africa, supposed to be of the first magnitude, to which some adventurers from the Association instituted for promoting Discoveries in the interior of Africa, have attempted to penetrate. ${ }^{20}$

It is clear that the Sierra Leone Company's interest in developing new trading contacts with the African interior led directly to exploration, and that Thomas Clarkson and other abolitionists were familiar with travellers' accounts of West Africa.

The Company's attempts to implement ideas conceived and fashioned in the metropole meant that Sierra Leone emerged as a fiercely contested site in Britain and West Africa. As the nascent colony was located in an on-going area of slave supply, Company employees were brought into direct conflict with slave captains and European agents resident on the coast and at the slave fort at Bunce Island in the Sierra Leone estuary (Plate 3). The influx of voluntary and coerced migrants into the colony over the following two decades also resulted in a complex interplay among neighbouring Africans, European officials, missionaries, traders, and settlers of African origin and descent with differing experiences of enslavement and freedom in the Americas. The historiography of this early phase of the colony has typically placed most emphasis on the Company's fractious relationship with its settler population, comprised mainly of black loyalists who, in the aftermath of the American Revolution, resettled in Nova Scotia and then migrated to Sierra Leone in the hope of making their

${ }^{19}$ Postscript to the Report, 1791, p. 4.

${ }^{20}$ Substance of the Report, 1794, pp. 141-3. At a meeting of the African Association on 23 July 1794 it was resolved, 'That Mr. Mungo Park having offered his Services to the Association as a Geographical Missionary to the interior countries of Africa; and appearing to the Committee to be well qualified for the Undertaking, his offer be accepted ...': Robin Hallett, ed., Records of the African Association 1788-1831, London, 1964, pp. 157-8; Robin Hallett, The Penetration of Africa. European Enterprise and Exploration Principally in Northern and Western Africa up to 1830. Vol. I to 1815, London, 1965, pp. 321-65. 
children 'free and happy'. ${ }^{21}$ This paper adopts a different perspective by examining the relationship between the Company's abolitionist programme and the wider processes of exploration and scientific discovery which were beginning to affect West Africa in the late eighteenth and early nineteenth centuries. This involves an assessment of how abolitionists constructed their case for reform, as well as the strategies deployed by Company employees to implement their plans in West Africa. The concluding part of this discussion draws together a number of, admittedly indirect, strands of evidence to assess reactions among indigenous Africans who encountered or interacted with the Company in different ways.

\section{II}

In their attempts to implement this ambitious scheme of reform for Africa, Company directors raised investment capital of $£ 235,000$ (equivalent to approximately $£ 13$ million in 2005$)^{22}$ from shareholders concentrated heavily in London, the Midland counties and the industrializing counties of Derbyshire, Lancashire and Yorkshire. The purchase of shares, priced at $£ 50$ each, was presented as a good business investment in new and emerging markets and as a way of compensating Africa for the injuries inflicted by the slave trade. It also had the effect no doubt of drawing British and European shareholders, and their networks of family and friends, into discussion of matters relating to Africa. The profile of 1,833 shareholders who invested during the first flourish of enthusiasm between 1791 and 1792 indicates that the Company enjoyed the support not only of leading abolitionists, bishops and clergy, but also prominent figures in business, commerce and politics. ${ }^{23}$ Leading industrialists and entrepreneurs were

${ }^{21}$ The Company report of 1794 indicated that 1,131 Nova Scotian settlers arrived at Freetown in a fleet of sixteen vessels early in 1792 . Of 1,196 who had embarked in Nova Scotia, sixty-five had perished during the voyage. In a petition to the directors of the Sierra Leone Company in October 1793, representatives of the Nova Scotian settlers drew attention to how 'we have feeling the same as other Human Beings and would wish to do every thing we can for to make our Children free and happy after us but as we feel our selves much put upon $\&$ distressed by your Council here we are afraid if such conduct continues we shall be unhappy while we live and our Children may be in bondage after us'. Substance of the Report, 1794, p. 7; Christopher Fyfe, ed., "Our Children Free and Happy": Letters from Black Settlers in Africa in the 1790s, Edinburgh, 1991, p. 37.

${ }_{22}$ This calculation is based on The National Archives currency converter, which offers a calculation based on prices for 2005: http://www.nationalarchives.gov.uk/currency/results.asp\#mid, accessed 20 January 2014. Initially, it was proposed that capital of $£ 100,000$ should be raised. In the Company report of 1794 , reference was made to the 'enlargement of the Company's capital, which was raised to the sum of $£ 235,280$ '. Substance of the Report of the Court of Directors of the Sierra Leone Company to the General Court Held at London on Wednesday the $19^{\text {th }}$ of October, 1791, London, 1791, pp. 44-5, 54, 56-61; Substance of the Report, 1794, p. 7.

${ }^{23}$ The pattern of shareholding in the Company is currently the subject of an on-going research project with Dr. Nicholas Evans at the Wilberforce Institute for the study of Slavery and Emancipation, University of Hull. Evans and Schwarz have constructed a database containing details of the 1,833 shareholders and have cross-referenced this information with newspapers, trade directories and other lists of subscribers from the period. The names of the subscribers are included in Carl Bernhard Wadström, An Essay on Colonization, Particularly Applied to the Western Coast of 
listed among those who invested in the first issue of shares. Erasmus Darwin purchased one share, Sir Richard Arkwright of Bakewell in Derbyshire purchased three, and Matthew Boulton of Soho in Birmingham and Josiah Wedgwood of Etruria in Staffordshire each purchased two shares. Hannah More (Figure 3) and other female subscribers accounted for nine per cent of shareholders, and this was an important way of engaging women in a respectable form of abolitionist protest that linked the market with moral consumer choices.

Interest in the commercial and philanthropic aspects of the scheme rather than its Christian complexion, is reflected in the presence of twelve Sephardi and Ashkenazi Jews among the shareholders, including the prominent financiers Benjamin and Abraham Goldsmid, and Isaac Baruch Lousada, a merchant of Devonshire Square whose family had direct connections to slavery and sugar cultivation in the West Indies. ${ }^{24}$ Lousada was among a number of subscribers who also invested in the Bulama Island scheme in 1792, a commercial venture based on European colonization on an island located some three hundred miles north of Sierra Leone. ${ }^{25}$ The presence of Carl Bernhard Wadström, a Swedish traveller and promoter of African colonization schemes, points to a wider European interest in the Company's abolitionist proposals. ${ }^{26}$ The list of shareholders did not include, however, any members of the Saturday's Club responsible for the formation of the Association for Promoting the Discovery of the Interior Parts of Africa three years earlier. As Robin Hallett has noted, there were areas of overlapping interest between the Sierra Leone Company and the African Association but 'it was the Company which showed the greater interest, more than half its Directors being members of the Association .... ${ }^{27}$ A. Adu Boahen emphasizes how a number of leading members of the African Association were 'determined anti-abolitionists', and that the key factor that brought together the members of the Saturday's Club was not abolition,

\footnotetext{
Africa, with Some Free Thoughts on Cultivation and Commerce, also Brief Descriptions of the Colonies already Formed, or Attempted...in Africa, including those of Sierra Leone and Bulama, London, 1795, pp. 341-53.

${ }^{24}$ Nicholas J. Evans and Suzanne Schwarz, 'Janus-faced Imperialists: Jews and the West Coast of Africa, 1787-1884'. Paper presented at a conference on 'Jews, Colonialism and Post-Colonialism', Kaplan Centre for Jewish Studies and Research, University of Cape Town, 8 April 2013.

${ }_{25}$ 'List of the Original Subscribers to the Association Formed in 1792, for Cultivating the Island of Bulama', in Carl B. Wadström, An Essay on Colonization, pp. 359-61; Christopher Fyfe, A History of Sierra Leone, London, 1962, p. 35; P. E. H. Hair, 'Beaver on Bulama', Boletim Cultural da Guiné Portuguesa, 58, 1960, pp. 360-83.

${ }^{26}$ Kate Hodgson, "'Dedicated to the Sound Politicians of all the Trading Nations of Europe" Sierra Leone and the European Colonial Imagination', in Paul E. Lovejoy and Suzanne Schwarz, eds, Slavery, Abolition and the Transition to Colonialism in Sierra Leone, Trenton, NJ, forthcoming 2014.

${ }^{27}$ Hallett, The Penetration of Africa, pp. xvi, 193-6, 212-14, 269-70, 273. For a discussion of the directors of the Sierra Leone Company who were members of the African Association, see below p. 19.
} 
'A JUST AND HONOURABLE COMMERCE': ABOLITIONIST EXPERIMENTATION

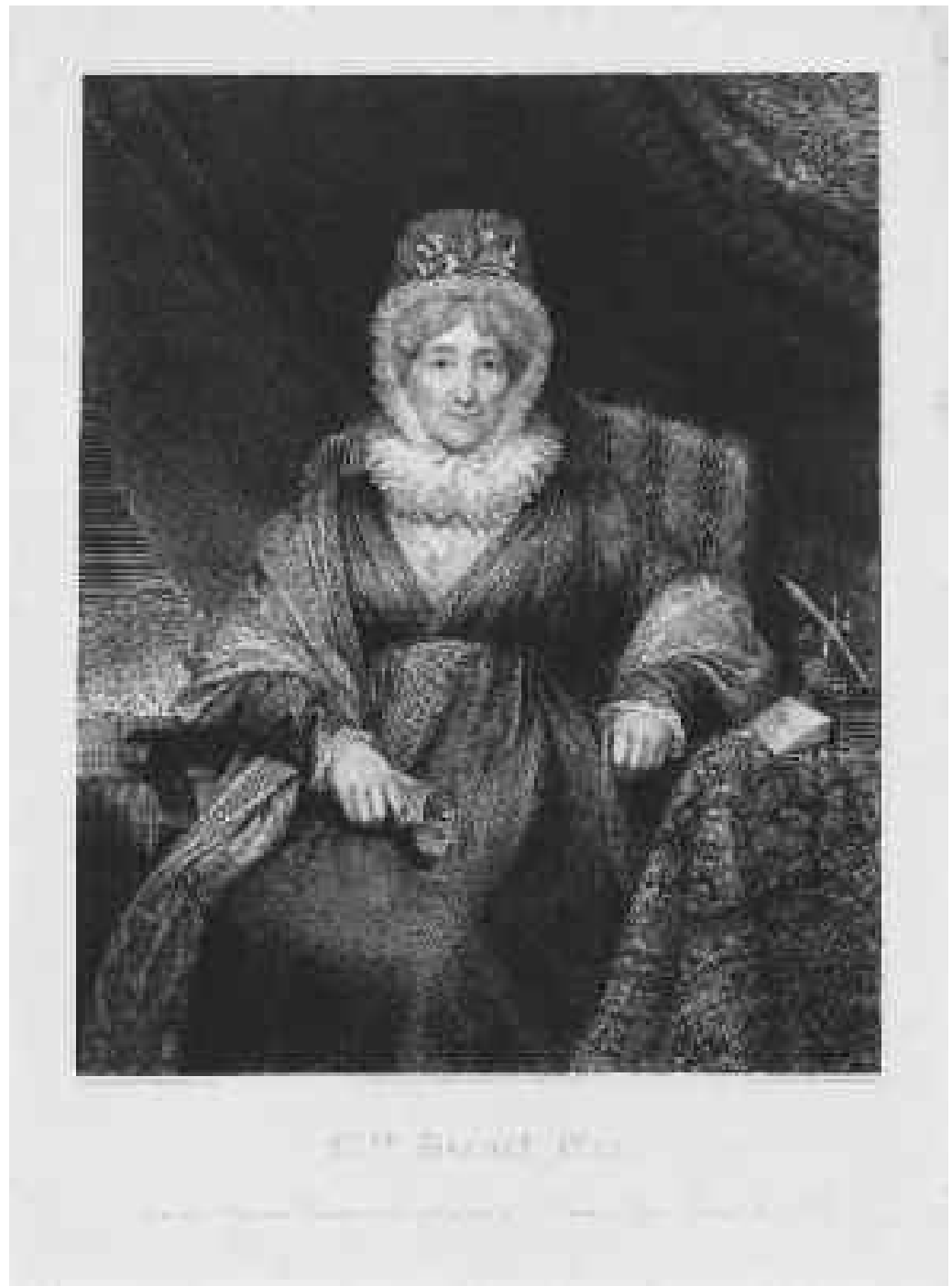

Figure 3. Mrs. Hannah More, 1824. PY6082. (C) National Maritime Museum, Greenwich, London. 
humanitarianism or Evangelicalism but 'their common interest in natural history, particularly botany'. Bryan Edwards, Secretary of the African Association, was a defender of slavery and the West India interest. ${ }^{28}$ Sir Joseph Banks, the first Treasurer of the African Association, was primarily interested in science, especially botany, and it was this factor that shaped his interest in the Sierra Leone project. As Kup points out, 'Banks's interest in Sierra Leone was wholly scientific; he was in fact an anti-Abolitionist'. ${ }^{29}$ When William Gilbert offered to cement a closer relationship between the African Association and the Sierra Leone Company by going to Africa, this was rejected by Banks:

That as the principal view of his design tended to colonization and civilization of the People of Africa, it did not in my opinion coincide with the purpose of the Association in its present state. We are first to explore and hereafter might civilize and colonize but not at present. ${ }^{30}$

The main motives of the African Association were commercial and scientific, and although some individual abolitionists were involved in the African Association, they were a minority. Boahen notes that:

Nowhere in the minutes of the committee of the Association still extant from 1788 to 1809 , nor in those of its annual general meetings throughout its existence from 1788 to 1831, was either legitimate trade or the abolition of the slave trade mentioned. ${ }^{31}$

The balance of altruism and self-interest shaping individual investments in the Sierra Leone Company is difficult to gauge, but Company directors emphasized the profits that would accrue to shareholders and the nation at large through trade in the agricultural riches of Africa. The image of Sierra Leone presented in the first published Company report of October 1791 was one of tropical abundance in which 'Nature appears to have been extremely liberal, and to have poured forth her treasures with an unsparing hand ...', ${ }^{32}$ a quotation taken directly from the pro-slavery account of Lieutenant Matthews in his $A$ Voyage to the River Sierra-Leone, on the Coast of Africa published in $1788 .^{33}$ The

${ }^{28}$ Olwyn M. Blouet, 'Bryan Edwards, F.R.S., 1743-1800', Notes and Records of the Royal Society of London, 54, 2, May 2000, pp. 215-22.

${ }^{29}$ Hallett, Records of the African Association, pp. 16-17; Alexander Peter Kup, ed., Adam Afzelius Sierra Leone Journal, 1795-1796, Uppsala, Studia Ethnographica Uppsaliensia, 27, 1967, p. 1.

${ }^{30}$ I am grateful to Professor Roy Bridges for this quotation drawn from copies of the Banks papers held at the Royal Geographical Society Archives: Gilbert to Beaufoy, 19 August 1792 with Banks's comments. Gilbert's proposal is referred to briefly by Hallett, Records of the African Association, p. 287.

${ }^{31}$ A. Adu Boahen, Review of Records of the African Association, edited with an Introduction by Robin Hallett, in Journal of African History, 6, 3, 1965, pp. 420-3; A. Adu Boahen, Britain, the Sahara, and the Western Sudan 1788-1861, Oxford, 1964, pp. 1-10.

32 Substance of the Report, 1791, pp. 26-7.

${ }^{33}$ John Matthews, A Voyage to the River Sierra-Leone, on the Coast of Africa, London, 1788, p. 63. 
remainder of Matthews's sentence, also included in the Company report, stated that in most cases the indolence of the natives prevents their reaping those advantages, of which an industrious nation would possess themselves' ${ }^{34} \mathrm{By}$ including this negative representation of Africans, the directors no doubt intended to highlight the potential for transformation which would result from the Company's intervention in West Africa. ${ }^{35}$ The directors' report stated confidently that 'the Peninsula of Sierra Leone, being one of the healthiest and most fertile spots on the whole Coast of Africa, has been selected for the trial of this interesting experiment'. ${ }^{36}$ The potential for producing sugar with free African labour at more competitive rates than in the West Indies was central to the vision of a profitable and ethical commerce, although the benefits to be derived from the import of raw materials such as indigo and cotton were emphasized in a context of increasing British industrialization. ${ }^{37}$

The employment of European officials to manage the 'infant colony' at Freetown and to implement the Company's reforming vision drew heavily on shareholder funds. Consequently, the absentee directors, acutely aware of their accountability to shareholders, attempted to maintain control over their employees by sending out regular instructions. This had clear limitations as, with the exception of Sir Charles Middleton and Sir George Young who had served as naval officers off the coast of West Africa, the board of directors was comprised of men who had no direct knowledge of the areas they were attempting to influence. Henry Thornton, Chairman, attempted to compensate for this lack of knowledge by instructing leading abolitionist Thomas Clarkson to compile a report on the economic potential of Sierra Leone in 1791 (Figure 4).

Clarkson interpreted the 'true design' of his instructions to mean that he should focus mainly on the 'Productions of Africa' which 'could best forward the Commercial Interest of the Company which they represent ...'. As he had not visited Africa, Clarkson acknowledged that the evidence he could draw on for a report was limited and included 'such specimens of them as may have been brought to England from time to time and secondly to Oral Evidence \& thirdly to the writings of such persons as have visited that Continent ${ }^{\prime}{ }^{38}$ Clarkson made reference to 'an old Voyage to Africa' which provided information on the 'famous kola tree', and this may indicate that he was familiar with Richard Jobson's A Discovery of the River Gambra published in 1623 which mentions 'a kinde of Nuts they call Cola', or Jean Barbot's account of Guinea published in

\footnotetext{
${ }^{34}$ Substance of the Report, 1791, p. 26; Matthews, Voyage to the River Sierra-Leone, p. 63.

${ }^{35}$ After a number of years, Company directors began to draw on very similar stereotypes to account for the failure of their economic plans.

${ }^{36}$ Postscript to the Report, 1791, p. 6.

${ }^{37}$ Substance of the Report, 1791, p. 43; Postscript to the Report, 1791, pp. 4-5.

${ }^{38}$ British Library, Add MS 12131, Collection of Papers Relative to Sierra Leone [hereafter BL, Sierra Leone], 'Letter Addressed to the Chairman of the Sierra Leone Company by the Revd. Mr. Thomas Clarkson', ff. 4r, 9r.
} 


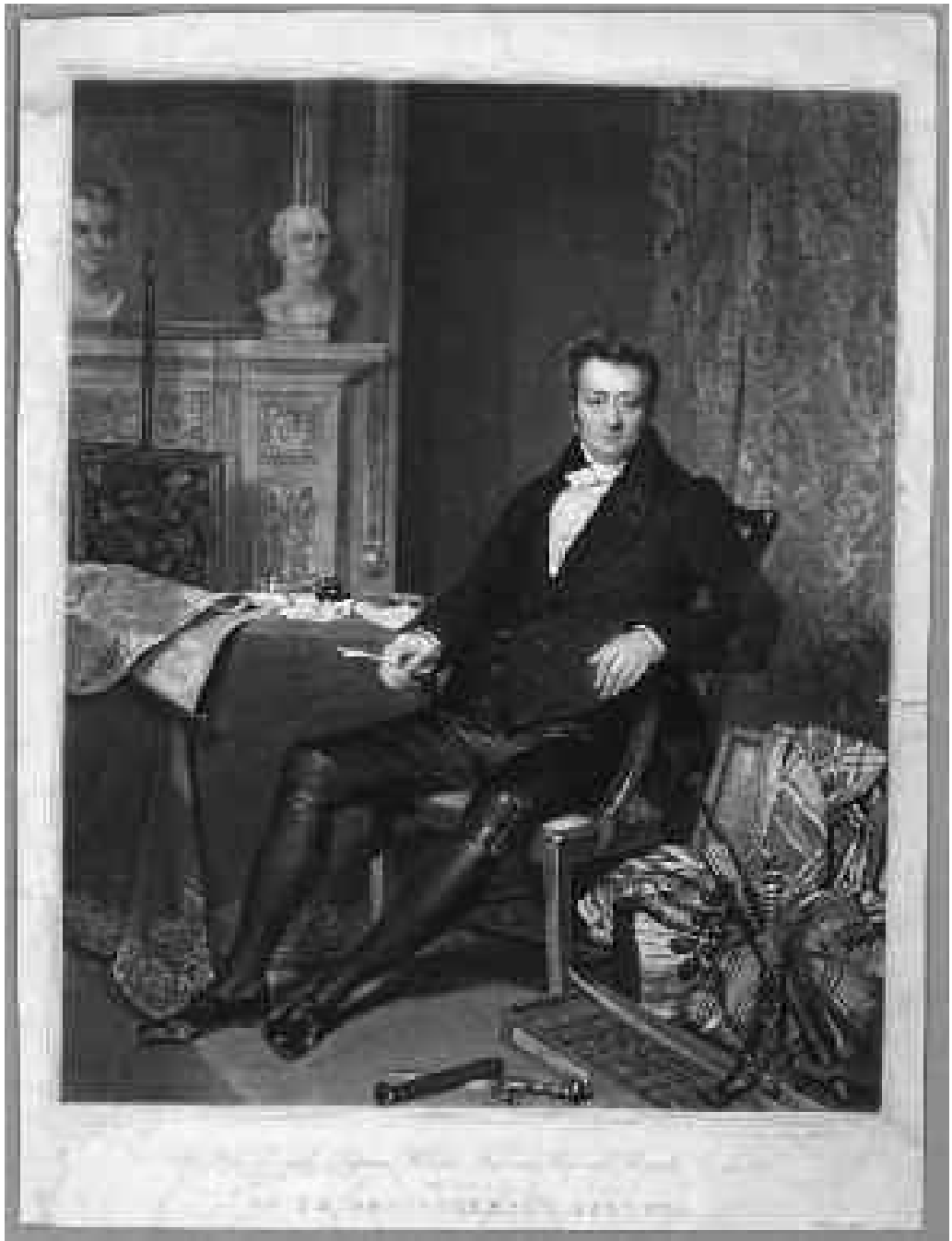

Figure 4. Thomas Clarkson, 1760-1846, circa 1825. FO869 (c) National Maritime Museum, Greenwich, London. Clarkson is depicted with his specimen chest of African products. 
London in 1732 which referred to 'a fruit called "cola" and by others, "cocters", which quenches the thirst and makes water delicious to those who make use of it ${ }^{39}{ }^{39}$ It appears that Clarkson did not read the original travel accounts but relied instead on Anthony Benezet's Some Historical Account of Guinea, a work which he referred to having read in his history of abolition. In his History, Clarkson referred to seeing an advertisement for Benezet's book and that he 'hastened to London to buy it'. He explained that:

In this precious book I found almost all I wanted. I obtained, by means of it, a knowledge of, and gained access to, the great authorities of Adanson, Moore, Barbot, Smith, Bosman and others. It was of great consequence to know what these persons had said upon this subject. For, having been themselves either long resident in Africa, or very frequently there, their knowledge of it could not be questioned ... Writing too at a time, when the abolition was not even thought of, they could not have been biassed with any view to that event. ${ }^{40}$

Benezet's Account summarized material from earlier travel writings on Africa, and presented a picture of a landscape abounding 'with grain and fruits, cattle, poultry, \&c.', which as Christopher Brown has noted 'seemed to anticipate, and perhaps even encouraged, later abolitionist emphasis upon legitimate trade'. ${ }^{41}$ Benezet made specific reference to the travels of André Brüe, Richard Jobson and Willem Bosman, and relied heavily on Thomas Astley's New General Collection of Voyages and Travels published in four volumes between 1745 and $1747 .{ }^{42} \mathrm{~A}$ list of books and pamphlets in Clarkson's possession in 1813 included Alexander Falconbridge's Account of the Slave Trade on the Coast of Africa, John Newton's Thoughts upon the African Slave Trade and C. B. Wadström's Observations on the Slave Trade \& a Description of Some Parts of the Coast of Guinea published in 1789 . No other travel accounts were listed. ${ }^{43}$

${ }^{39}$ Both of these accounts are available in Hakluyt editions. David P. Gamble and P. E. H. Hair, eds, The Discovery of River Gambra by Richard Jobson 1623, vol. II, London, Hakluyt Society, $3^{\text {rd }}$ ser., 2, 1999, p. 134, n. 4. Barbot included an illustration of a kola nut in his account. P. E. H. Hair, Adam Jones and Robin Law, eds, Barbot on Guinea. The Writings of Jean Barbot on West Africa 1678-1712, vol. I, London, Hakluyt Society, $2^{\text {nd }}$ ser, 175, London, 1992, pp. ix, 188. These references are to Cola nitida. There are more than forty varieties of kola nut: 'C. nitida, C. acuminata, C. verticillata, and $C$. anomala ... are the most common of the edible species'. C. nitida has 'been a major commodity in West African trade for many centuries ...'. See, Paul E. Lovejoy 'Kola in the History of West Africa', Cabiers d'Études africaines, 20, 1980, pp. 97-134 (97-8).

${ }^{40}$ Thomas Clarkson, The History of the Rise, Progress, and Accomplishment of the Abolition of the African Slave-Trade by the British Parliament, vol. I, London, 1808, pp. 169-70, 207-8.

${ }^{41}$ Benezet claimed that 'Guinea affords an easy living to its inhabitants, with but little toil'. Anthony Benezet, Some Historical Account of Guinea, New Edition, London, 1788, pp. 1, 5; Brown, 'Origins of "Legitimate Commerce"', p. 143.

${ }^{42}$ See, for example, Benezet, Some Historical Account of Guinea, pp. 7-25; Maurice Jackson, Let This Voice be Heard. Anthony Benezet, Father of Atlantic Abolitionism, Philadelphia, PA, 2009, pp. 81-6.

${ }^{43}$ St. John's College Library, Cambridge, Clarkson Papers, 'List of Publications in Thomas Clarkson's Possession, 1813', documents 40 and 153. 
Clarkson's report drew extensively on ideas and evidence that had already been published in his earlier pamphlets between 1787 and 1789. In 1787, his $A$ Summary View of the Slave Trade, and of the Probable Consequences of its Abolition had emphasized how trade in 'cotton, indigo, tobacco, rice, coffee, spices, drugs, mahogany, dying woods, wax, ambergris, honey, ivory, gold \&c. would be of national advantage .... ${ }^{44}$ In the following year, his pamphlet, $A n$ Essay on the Impolicy of the African Slave Trade. In Two Parts, included a detailed explanation of the 'numberless treasures of the African soil' that would provide a basis for a new profitable commerce that would 'compensate for the loss of America' and 'break the monopoly of the Dutch' in the import of spices. In this work, dedicated to William Wilberforce, Clarkson made clear that his views could be corroborated by 'living evidence', as well as by the fact that 'the greatest part of them I have now specimens in my possession'. ${ }^{4}$

Clarkson's report was accompanied by an itemized list of wood, cloth and plant specimens, which corresponds closely with his touring chest of African products (Figure 4) collected during his 'water expeditions' to Liverpool, London, Bristol and the naval ports of Chatham, Portsmouth and Plymouth. ${ }^{46}$ He expressed surprise that so many specimens of the 'Productions of Africa' were available, as 'Few persons who go to that part of the World go for any other purpose than that of collecting slaves .... ${ }^{47}$ The way the report was written gives the impression that Clarkson gave a practical demonstration for the directors in which he held up or pointed to his exhibits as he referred to them. A sample of cotton, listed as item 11, was 'collected in a wild state near the River Gambia', and was reported to be 'superior in quality to any from St. Domingo or the West Indian Islands and as approaching the Best Berbice, it has been valued at about two shillings a pound'. The 'good quality of the African cotton' was demonstrated

${ }^{44}$ Thomas Clarkson, A Summary View of the Slave Trade, and of the Probable Consequences of its Abolition, London, 1787, p. 11.

45 Thomas Clarkson, An Essay on the Impolicy of the African Slave Trade, London, 1788, pp. iii, $14,17,20$. In the following year, he noted how the productions of Africa mentioned in his Essay on the Impolicy of the African Slave Trade 'are not imaginary, but real, for of the existence of all of them living testimony can be produced, and of most of them ocular demonstration can be given ...'. Thomas Clarkson, An Essay on the Comparative Efficiency of Regulation or Abolition, as applied to the Slave Trade. Shewing that the latter only can remove the Evils to be found in that Commerce, London, 1789, p. 67.

${ }^{46}$ In his History, Clarkson referred to visiting ships moored in the Thames which traded with Africa. He noted how Captain Williamson of the Lively traded in 'ivory, beeswax, Malaguetta pepper, palm-oil, and dye woods'. He described how, 'I obtained specimens of some of these, so that I now became possessed of some of those things of which I had only read before'. A visit to Liverpool furnished him with samples of 'gum ruber astringens [sic], of cotton from the Gambia, of indigo and musk, of long pepper, of black pepper from Whidah, of mahogany from Calabar, and of cloths of different colours, made by the natives, which, while they gave other proofs of the quality of their own cotton, gave proofs, also, of the variety of their dyes'. Clarkson, History, vol. I, pp. 237, 373. Black pepper from Ouidah is listed among the samples in his report on Sierra Leone.

${ }^{47}$ BL, Sierra Leone, 'Letter Addressed to the Chairman of the Sierra Leone Company', f. 7r. 
by reference to a piece of 'white cloth A which was made by the Natives living between the Senegal \& the Gambia of the cotton growing there'. 48 'Two blue and white' pieces of cloth labelled $\mathrm{B}$ and $\mathrm{C}$ had been dyed using indigo found on the coast, and indigo 'in its rudest state' was presented as specimen 13. Item 18 was identified as the 'bag of the Musk or Civet Cat from the Windward Coast'. Wood samples, listed from A to W, included a wooden instrument (sample V) made of a 'strong useful wood' that would be 'particularly valuable for shipbuilding if it could be procured in large Logs', and a 'species of Camwood from Sierra Leon' was considered 'fit both for Cabinet makers and Dyers use'. A sample of barwood from Sierra Leone was displayed with vial 2 which 'yields its Colour'. Item $T$ was described as a 'specimen of wood which according to the account given by the Discoverer of it as well as in consequence of a subsequent tryal affords a more beautiful \& permanent Yellow Dye than any in use in this Country. ${ }^{49}$

In gathering testimony from individuals with first-hand knowledge of Africa, Clarkson spoke to slave traders in Liverpool, including the 'Liverpool delegate' Robert Norris who appeared to lend support to the abolitionist view that the slave trade prevented Africans from cultivating 'many of the valuable productions of their own soil'..$^{50}$ Clarkson reported that he met Norris at his house in Liverpool six times, and that in one of their conversations 'on the subject of African productions, he told me, that he had brought some black pepper from Whydah; which black pepper he gave a specimen of, stating, at the same time, that such specimen was one argument of the impolicy of the Slave Trade. ${ }^{51}$ In the course of a tour in 1788, Clarkson collected oral testimony from over twenty people who had visited Africa or the West Indies, including several captains of Royal Navy ships. In the case of witness no. XVII, it was reported that during his

${ }^{48} \mathrm{Ibid}$., f. $5 \mathrm{r}$. It is unclear whether Clarkson was aware that cotton-textile manufacture was already well-established in Africa and was the basis of trading in internal and external markets. The internal demand was particularly strong. Law, Schwarz and Strickrodt, 'Introduction', in Commercial Agriculture, the Slave Trade \& Slavery in Atlantic Africa, p. 12.

${ }^{49}$ BL, Sierra Leone, 'Letter Addressed to the Chairman of the Sierra Leone Company', ff. 5r, 6r, 6v, 7r. In his Essay on the Impolicy of the African Slave Trade published in 1788, Clarkson discussed the circumstances leading to the return of a specimen of bark to Britain 'that produced a very valuable yellow dye, and far beyond any other ever in use in this country'. Clarkson, Essay on the Impolicy of the African Slave Trade, p. 9.

${ }^{50}$ Robert Norris is also known for his book entitled Memoirs of the Reign of Bossa Ahadee, King of Dahomey published in 1789. Curtin describes this book as a vitriolically anti-African history of Dahomey during the middle decades of the eighteenth century .... Curtin, Image of Africa, p. 24.

${ }^{51}$ Sheila Lambert, ed., 'Minutes of Evidence on the Slave Trade 1790', House of Commons Sessional Papers of the Eighteenth Century, Wilmington, DE, 1975, vol. 73, pp. 67-70. Clarkson recorded that, "With respect to the produce of Africa, Mr. Norris enumerated many articles in which a new and valuable trade might be opened, of which he gave me one, namely, the black pepper from Whidah before mentioned'. Clarkson, History, vol. I, p. 379. Robert Norris was one of the delegates selected by the Corporation of Liverpool to give testimony in defence of the slave trade in 1788 . F. E. Sanderson, 'The Liverpool Delegates and Sir William Dolben's Bill', Transactions of the Historic Society of Lancashire and Cheshire, 124, 1972, pp. 57-84 (67). 
visits to the coast of Africa in command of a Royal Navy vessel in 1781 and 1782, he saw 'growing spontaneously, cotton, indigo, and tobacco, ... peppers of various sorts, and woods of variegated green' ${ }^{52}$ Clarkson also cited evidence heard before the Select Committee of the House of Commons on the Slave Trade in 1790, including reference to plants and diverse types of manufacturing recorded by Wadström. In his testimony, Wadström reported that indigo 'grows abundantly all over the country, and even so plentiful, that it often spoils their ground for millet and rice plantations'. He also drew attention to his collection of a 'kind of beans used for colouring' in Africa, which was available for inspection if required. ${ }^{53}$ Clarkson also cited testimony by Captain Thomas Boulden Thompson, ${ }^{54}$ which indicated that Sierra Leone could produce a variety of gums, peppers and spices. ${ }^{55}$ Clarkson noted how Captain Thompson's reference to 'wild Nutmegs' was hearsay, but he considered it broadly reliable as 'in one of the collections of Voyages to Africa the nutmeg is mentioned as having been frequently seen in the Kingdom of Congo \& as growing there .....$^{56}$

The evidence on which Clarkson relied most heavily was John Matthews's Voyage to the River Sierra-Leone published in 1788, even though this former naval officer concluded that 'slavery can never be abolished in a country like Africa.... 57 Despite the pro-slavery bias of Matthews's account, written during a period when he was employed by a private commercial company, Clarkson gave credence to his testimony and cited his views at least fifteen times. Abolitionists were clearly drawing extensively on the evidence of slave traders, as well as the knowledge of other merchants and travellers who were not necessarily motivated by anti-slavery principles. Interest in developing commercial agriculture and trade in African commodities other than slaves was not restricted to abolitionist sympathizers,

${ }^{52}$ Thomas Clarkson, The Substance of the Evidence of Sundry Persons on the Slave-Trade, Collected in the Course of a Tour Made in the Autumn of the Year 1788, London, 1789, pp. 100-101.

${ }^{53}$ Lambert, 'Minutes of Evidence on the Slave Trade 1790', House of Commons Sessional Papers of the Eighteenth Century, vol. 73, pp. 32-3.

${ }^{54}$ Captain Thomas Boulden Thompson, an officer in the Royal Navy, had first-hand knowledge of Sierra Leone as he had accompanied the original settlers to found the 'Province of Freedom' in 1787. Thompson negotiated the acquisition of land with King Tom on 11 June 1787, but it was necessary for this to be renegotiated as Thompson had agreed it with King Tom, the 'local ruler' rather than his superior Naimbanna 'who declined to accept it'. Thompson's signature is included on the original treaty, together with the marks of King Tom, Chief Pabongee and Queen Yammacouba. Fyfe, History, pp. 18-21, 24, 35, 45; Christopher Fyfe, Sierra Leone Inheritance, London, 1964, pp. 112-13.

${ }^{55}$ In his testimony, Thompson stated that 'I believe there are several species of Gum in and about Sierra Leone, but the principal is the Gum Copal'. He also reported how, 'the Cardamum is in great plenty; I have seen some black pepper; red peppers of many species are in abundance; and I have been told that there are wild nutmegs, the island of Saint Thomas belonging to the Portuguese abounds in cinnamon which grows spontaneously, but I never saw any on the continent of Africa, although I think it is equally calculated to produce it'. Lambert, 'Minutes of Evidence on the Slave Trade 1790', House of Commons Sessional Papers of the Eighteenth Century, vol. 73, pp. 174, 177.

${ }^{56} \mathrm{BL}$, Sierra Leone, 'Letter Addressed to the Chairman of the Sierra Leone Company', f. 8v.

${ }^{57}$ Matthews, Voyage to the River Sierra-Leone, p. 148. 
which is illustrated in Malachy Postlethwayt's writings in the 1750s promoting ideas of alternative forms of trade in agricultural commodities and by the Royal African Company's experimentation with the growth of indigo in the late seventeenth century on Tasso Island, located near Bunce Island (Plate 4). ${ }^{58}$

Clarkson's research was no doubt extensive by the standards of the day, but it was still partial. The report to the directors did not mention earlier failed experiments in cultivation by the Royal African Company or the Dutch West India Company, even though these attempts to cultivate cotton and other commodities on the Gold Coast were mentioned in testimony to the Committee of the Privy Council on the Trade to Africa in 1788. Nor did Clarkson refer in this report to the Danish plantation experiment on the Gold Coast in 1788 or the work of earlier writers who had discussed the idea of European plantations in Africa, including John Atkins in his Voyage to Guinea, Brasil and the West Indies published in $1735 .{ }^{59}$ Although Postlethwayt is not mentioned in the report to the directors in 1791, Clarkson was aware of his ideas on alternative forms of commerce with Africa and had referred to them in his Essay on the Impolicy of the African Slave Trade three years earlier.$^{60} \mathrm{~A}$ list of books in Clarkson's possession in 1813 also included a note about 'Postlethwayt as a Writer to be quoted'. ${ }^{61}$ Clarkson's use of Lieutenant Matthews's work was highly selective and uncritical and he failed to notice, or at least take account of, factors that could impede the Company's objectives. Reflecting views of tropical abundance similar to those presented by the amateur botanist Henry Smeathman two years earlier, ${ }^{62}$ Clarkson was convinced that valuable cash crops including tobacco, sugar and cotton would flourish in Sierra Leone. His robust account of the large profits which could be derived from sugar cultivation was no doubt influenced by Matthews's erroneous report that 'sugar canes are a native plant, and grow wild to a size beyond any I ever saw in the West Indies' ${ }^{6}{ }^{63}$ In their report to shareholders in 1791, the directors indicated that reports from 'their own agents, and from various other quarters, exceedingly confirms the above account of Lieutenant Matthews'. ${ }^{64}$ This confidence was short-lived. The problems created by the reliance on Matthews's account were recognised by the Company's directors several years later. In the Company report of 1794 , it was explained that:

The Directors feel much regret at having to mention to the Proprietors, that the land adjoining to the settlement has proved by no means so good as every account

${ }^{58}$ Rodney, History of the Upper Guinea Coast, pp. 152-70; Law, Schwarz and Strickrodt, 'Introduction', pp. 11-12, 17; Brown, 'Origins of “Legitimate Commerce”', pp. 147-51.

${ }^{59} \mathrm{Law}$, Schwarz and Strickrodt, 'Introduction', pp. 8-16.

${ }^{60}$ Clarkson, Essay on the Impolicy of the African Slave Trade, pp. 20-21.

${ }^{61}$ St John's College Library, Cambridge, Clarkson Papers, 'List of Publications in Thomas Clarkson's Possession, 1813', document 40.

${ }^{62}$ Curtin, Image of Africa, pp. 58-61.

${ }^{63}$ Matthews, Voyage to the River Sierra-Leone, p. 53; Substance of the Report, 1791, p. 23.

${ }^{64}$ Substance of the Report, 1791, p. 26. 
received before the institution of the Company had led them to expect. The description given of it in the work of Lieutenant Matthews, to which they had in some measure trusted, is far more favourable than further observation of that particular part of the country would have justified. The Directors state this to be a disappointment of the most serious kind, to which may be ascribed many of the difficulties, and a great part of the unexpected charges that have attended the establishment of the colony. ${ }^{65}$

Based on his research, Clarkson made several key recommendations on developing a 'Plan of Trade' at Sierra Leone. He assumed, incorrectly as it later transpired, that the Nova Scotian settlers would provide the main labour source for cultivation in the colony. ${ }^{66}$ In addition, he emphasized how 'every encouragement should be given to the Natives in the neighborhood to induce them to let themselves out to work or to cultivate their own lands with a view of selling the produce to the Company'. ${ }^{67}$ Hence, when Watt reached Fuuta Jalon he insisted that the local population should learn to plough its ground with cattle and plant more cotton and he offered to send a plough on his return to Freetown. ${ }^{68}$ An important omission in Clarkson's report, however, is the lack of any consideration of African labour practices and land organisation and by what means plants reported as growing wild could be brought into cultivation.

Drawing heavily on Matthews's account of the river networks on the upper Guinea coast, Clarkson recommended 'Coast \& River expeditions' should be undertaken to give access to a vast network of inland trade. ${ }^{69} \mathrm{He}$ also recommended that trade should be opened by sending caravans of 'black persons $\&$ others going in a Body into the interior Country with Camels or Mules or any other beasts of burthen loaded with Merchandize on the Companys account ${ }^{\prime}{ }^{70}$ Although he was aware in very general terms of the movement of slave caravans and the links to Muslim societies and teachers, the quality of information on areas beyond the coast was extremely vague. Yet, Clarkson was optimistic that through his 'Plan of Trade' the Company would 'fall in ... with hundreds of Villages now unknown' through which 'we shall command the most valuable produce of all the Villages situate perhaps in a Tract of two thousand miles .... ${ }^{71}$ An idea which was not stated explicitly in Clarkson's report but which later appears in the directors' published reports is that by travelling inland they would bypass coastal middlemen, who were assumed to be committed to the slave trade, and encounter populations less corrupted by the

${ }^{65}$ Substance of the Report, 1794, pp. 15-16.

${ }^{66} \mathrm{BL}$, Sierra Leone, 'Letter Addressed to the Chairman of the Sierra Leone Company', f. $17 \mathrm{r}$.

${ }^{67}$ Ibid.

${ }^{68}$ Mouser, Journal of James Watt, pp. 25, 34, 38, 44, 59-60.

${ }^{69}$ Clarkson's description of the river networks follows very closely Matthews's account in Letter

II. Matthews, Voyage to the River Sierra-Leone, pp. 9-25.

${ }^{70} \mathrm{BL}$, Sierra Leone, 'Letter Addressed to the Chairman of the Sierra Leone Company', f. 18r.

${ }^{71}$ Ibid., f. 20r. 
profits of the slave trade who would be more receptive to their abolitionist message. ${ }^{72}$

\section{III}

The project of developing new forms of trade and cultivation required the acquisition of new sorts of knowledge about the African societies involved, so that even in the cases of those societies with which Europeans were already trading, there was scope for further 'exploration' and 'discovery'. Eight directors of the Sierra Leone Company were listed as members of the African Association by May 1792, which reflected their interests in science and in gathering intelligence on African economies and societies. William Wilberforce and Sir Charles Middleton had been members from at least 1790, but they were joined by a further six Company directors in 1792 (Joseph Hardcastle, Samuel Parker, Philip Sansom, Henry Thornton, George Wolff and Sir George Young). ${ }^{73}$ After securing the 'vote of two-thirds of the members present at any one meeting', the payment of a membership fee of five guineas entitled them to attend the annual General Meeting and to receive publications detailing the progress of travels focused principally on 'the approach to the Niger and the central Sudan by way of Cairo, Tripoli and the Gambia .... ${ }^{74}$ Despite his interest in gathering information on Africa from various sources, Thomas Clarkson was not listed as a member of the African Association. This did not preclude the possibility of maintaining contacts with influential members of the African Association who could be useful in promoting Clarkson's recommendations. Sir Joseph Banks, who served as both Treasurer and Secretary of the African Association at different points, had built up extensive experience as a traveller and 'field botanist' on voyages in the northern and southern hemispheres in the 1760s and 1770 s. $^{75} \mathrm{He}$ was, as Anna Agnarsdóttir has pointed out, 'one of the first naturalist explorers' and he sailed with Captain James Cook to the South Seas on the Endeavour. ${ }^{76}$ Banks subsequently made an important contribution to the development of Clarkson's ideas on agriculture through the supply of plant

72 Substance of the Report, 1794, pp. 107-8.

${ }^{73}$ Proceedings of the Association for Promoting the Discovery of the Interior Parts of Africa, London, 1790, pp. v-vii; Proceedings of the Association for Promoting the Discovery of the Interior Parts of Africa, London, 1791, pp. v-xi; Proceedings of the Association for Promoting the Discovery of the Interior Parts of Africa, London, 1792, pp. 21-4.

${ }^{74}$ Hallett, The Penetration of Africa, pp. 212-14, 269; Robin Hallett, 'The European Approach to the Interior of Africa in the Eighteenth Century', Journal of African History, 4, 2, 1963, pp. 191206 (201-6).

${ }^{75}$ Sir Joseph Banks resigned his position as Treasurer in 1804 after a period of sixteen years. He 'had acted as Secretary from 1795 to 1797 , and again in 1799, when Edwards was seriously ill'. Hallett, Records of the African Association, pp. 16-17; H. B. Carter, Sir Joseph Banks 1743-1820, London, 1988, pp. 241-3.

${ }^{76}$ Anna Agnarsdóttir, 'This Wonderful Volcano of Water'. Sir Joseph Banks Explorer and Protector of Iceland 1772-1820, Annual Lecture, Hakluyt Society, London, 2004, pp. 4-7. 
specimens and the recommendation of his 'Swedish protégé', Adam Afzelius, as Company botanist. ${ }^{77}$

The implementation of Clarkson's recommendations in his report on Sierra Leone led directly to increasing levels of travel and exploration on the upper Guinea coast. Even though their short and long distance journeys included visits to areas already well-known to English and Portuguese traders, journals and travel accounts written by Company employees and settlers frequently drew on the language of discovery to refer to crops or commodities which could form the basis of a new 'legitimate' trade. ${ }^{78}$ In that sense, employees of the Sierra Leone Company were drawing on a notion of economic 'discovery' similar to Richard Jobson's use of the term in Discovery of the River Gambra, an issue discussed by David Gamble and Paul Hair in the Hakluyt edition published in 1999. ${ }^{79}$

Adam Afzelius, the Swedenborgian botanist employed by the Company, considered that Sierra Leone provided vast potential for 'important discoveries' of flora and fauna. He was a pupil of Linnaeus and was regarded as one of the group of 'Linnaeus Apostles' ${ }^{80}$ During his period in Sierra Leone between 1792 and 1796, he employed the Swedish naturalist's system of classification. ${ }^{81}$ Shortly after his arrival at Freetown in May 1792, Afzelius reported how he went on shore and 'observed with rapture a new world of products' and 'immediately began to collect some of the many partly unknown $\&$ partly rare Plants surrounding me .... ${ }^{82} \mathrm{He}$ was aware that some plant specimens from Sierra Leone gathered by Henry Smeathman were among the collections of Sir Joseph Banks, but emphasized how 'None of these plants, however, have been made public in England, but in Germany \& France a few of them have been drawn \& described'. Afzelius's intention was to collect, describe and catalogue specimens for dispatch to the Court of Directors, as well as for Sir Joseph Banks and Dr. J. E. Smith ${ }^{83}$ who 'as my particular friends, promised me to receive $\&$ preserve safely all what I send them from hence. ${ }^{84}$ Eleven months later, Afzelius sent home 229 species

${ }^{77}$ Neil Chambers, 'Letters from the President: The Correspondence of Sir Joseph Banks', Notes and Records of the Royal Society of London, 53, 1, January 1999, pp. 27-57 (27-8, 41-2); Carter, Sir Joseph Banks, pp. 423-4; Hallett, The Penetration of Africa, pp. 273-4; Fyfe, History, p. 43; Hallett, Records of the African Association, p. 275; Sten Lindroth, 'Adam Afzelius: A Swedish Botanist in Sierra Leone, 1792-96', Sierra Leone Studies, New Series, June 1955, pp. 194-207.

${ }^{78}$ Mouser, 'Continuing British Interest', pp. 761-3,765.

${ }^{79}$ Gamble and Hair, The Discovery of River Gambra by Richard Jobson, p. 6, n. 3.

${ }^{80}$ Lindroth, 'Adam Afzelius. A Swedish Botanist in Sierra Leone', pp. 194-8.

${ }^{81} \mathrm{Kup}$, Adam Afzelius Sierra Leone Journal, pp. xii-xv, 3. Further information on Afzelius's work in Sierra Leone is contained in Lars Hansen, ed., The Linnaeus Apostles. Global Science and Adventure, Vol. IV, London and Whitby, 2009, pp. 399-661.

${ }^{82}$ BL, Sierra Leone, 'Mr. Afzelius's Letter from Sierra Leone', 29 December 1792', ff. 157r, 158r.

${ }^{83}$ This is a reference to Dr. James Edward Smith, founder of the 'Linnaean Society' in 1788. Afzelius 'contributed to Smith's English edition of Linnaeus's Flora Lapponica', Kup, Adam Afzelius Sierra Leone Journal, p. xiii; Carter, Sir Joseph Banks, pp. 191-2, 197, 240-1; Lindroth, 'Adam Afzelius. A Swedish Botanist in Sierra Leone', pp. 198-9.

${ }^{84}$ BL, Sierra Leone, 'Mr. Afzelius's letter from Sierra Leone', 29 December 1792, f. 159r. 

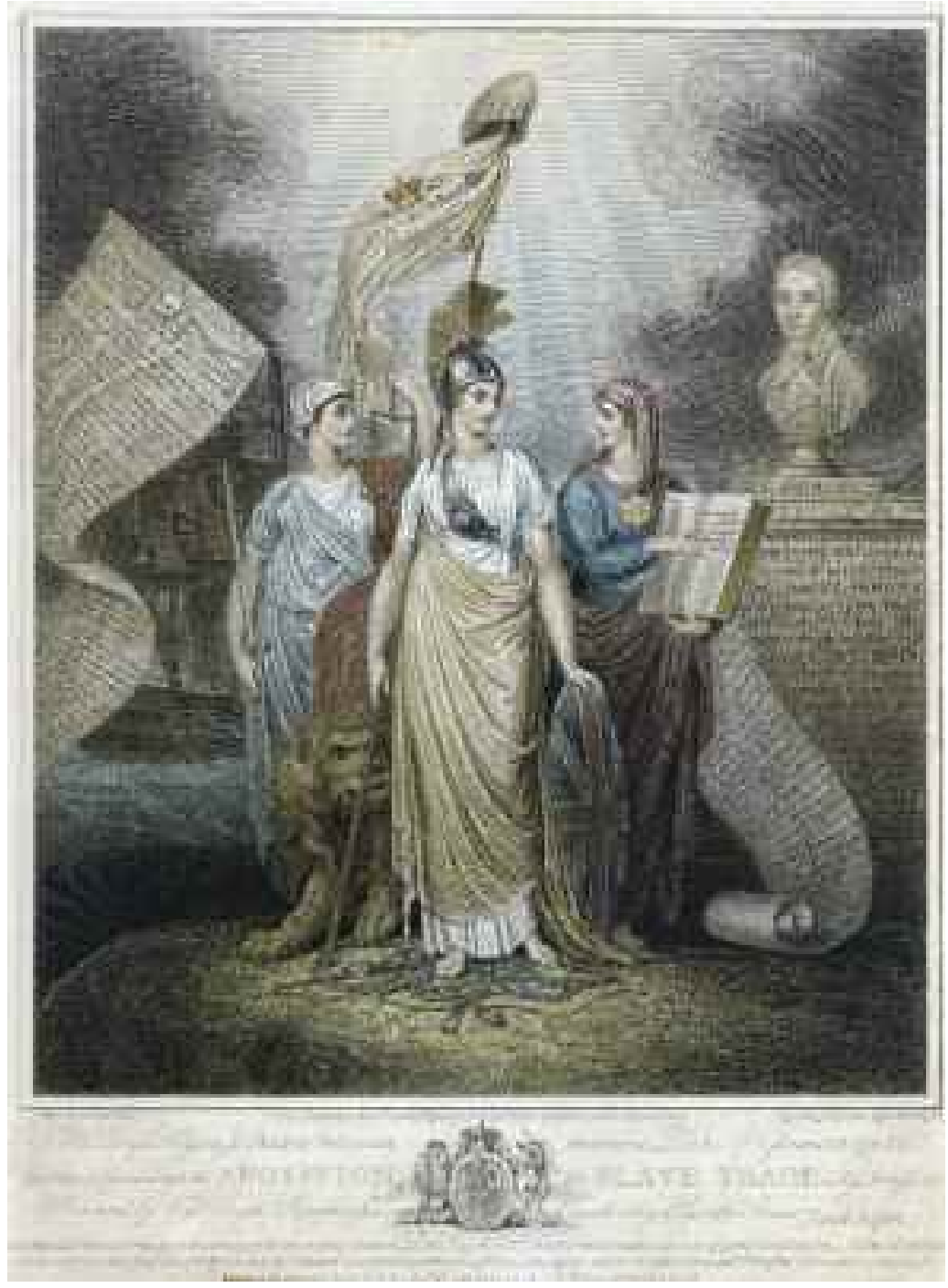

Plate 1. Plate to Commemorate the Abolition of the Slave Trade, 4June 1808. This handcoloured etching included a caption which referred to 'Britannia trampling on the emblems of slavery, holding a banner declaring the abolition and attending to the voice of justice and religion'. PY7367 (C) National Maritime Museum, Greenwich, London. 


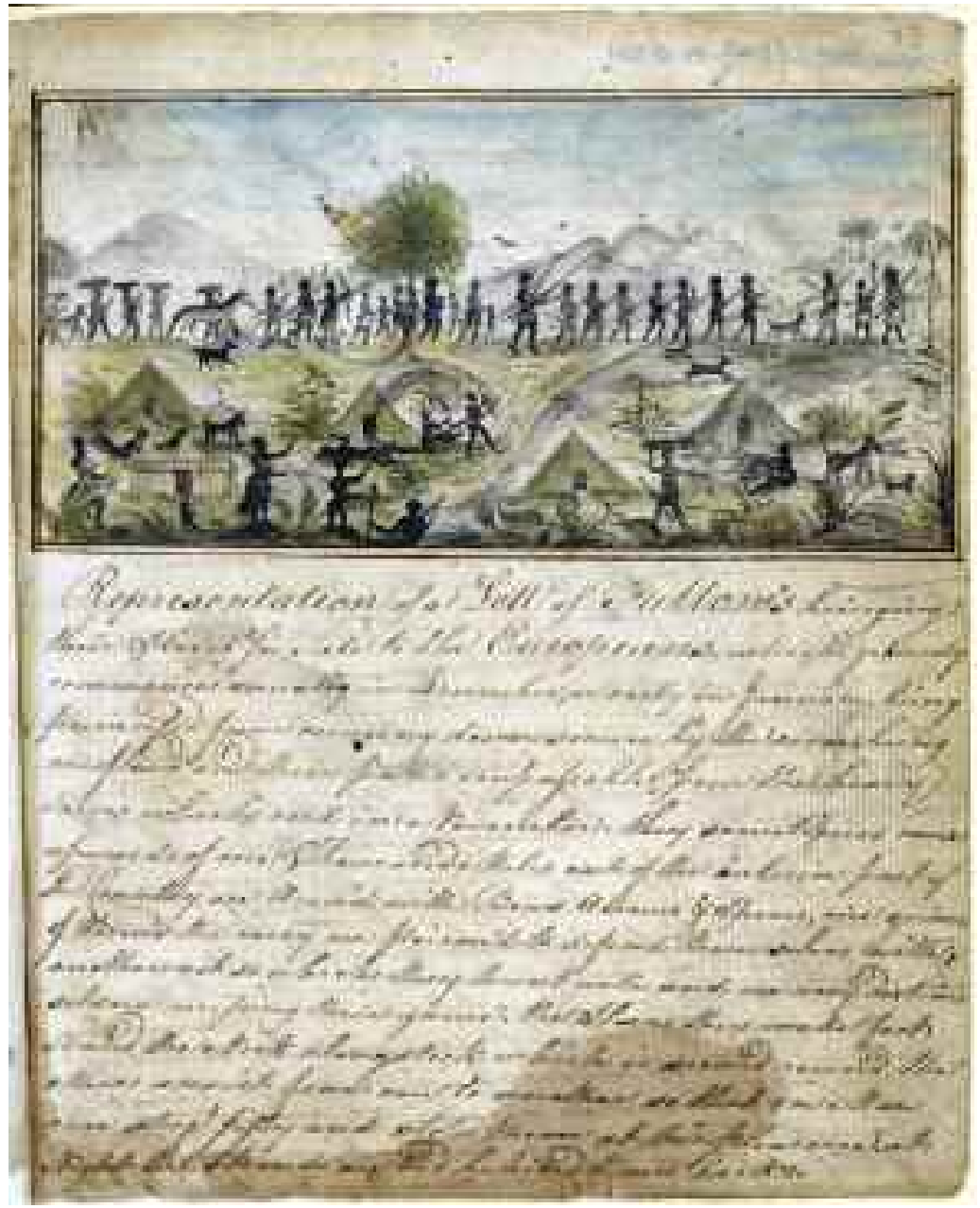

Plate 2. Image of a Slave Caravan from the journal of Samuel Gamble, captain of the slave ship Sandown, 1793. An entry underneath the image refers to 'Representation of a Lott of Fullow's [Fula] bringing their slaves for Sale to the Europeans'. D7596 (c) National Maritime Museum, Greenwich, London. 


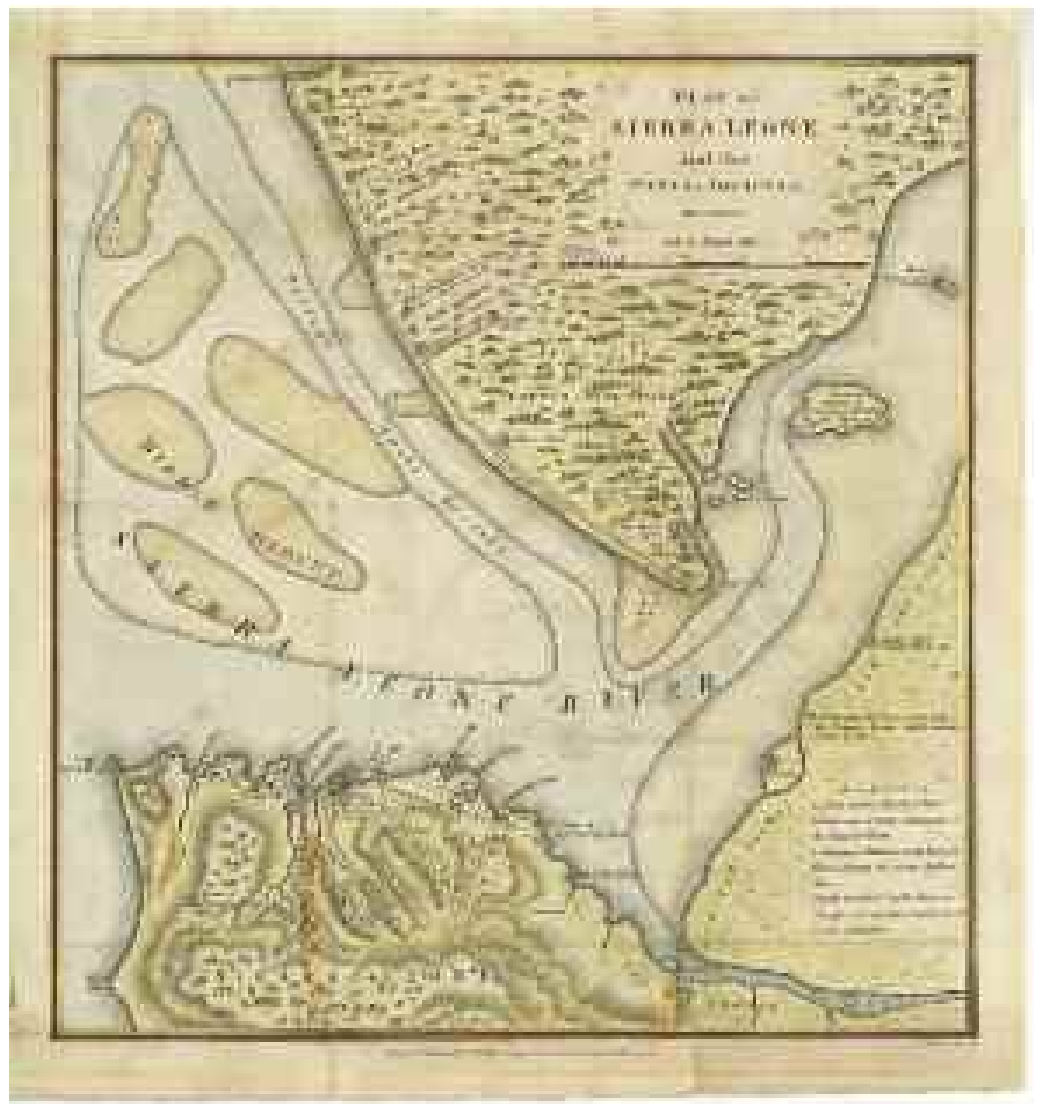

Plate 3. 'Plan of Sierra Leone and Parts Adjacent, MDCCXCIV'. This plan was published in Substance of the Report Delivered by the Court of Directors of the Sierra Leone Company to the General Court of Proprietors on Thursday the 27th March, 1794, London, 1794. 


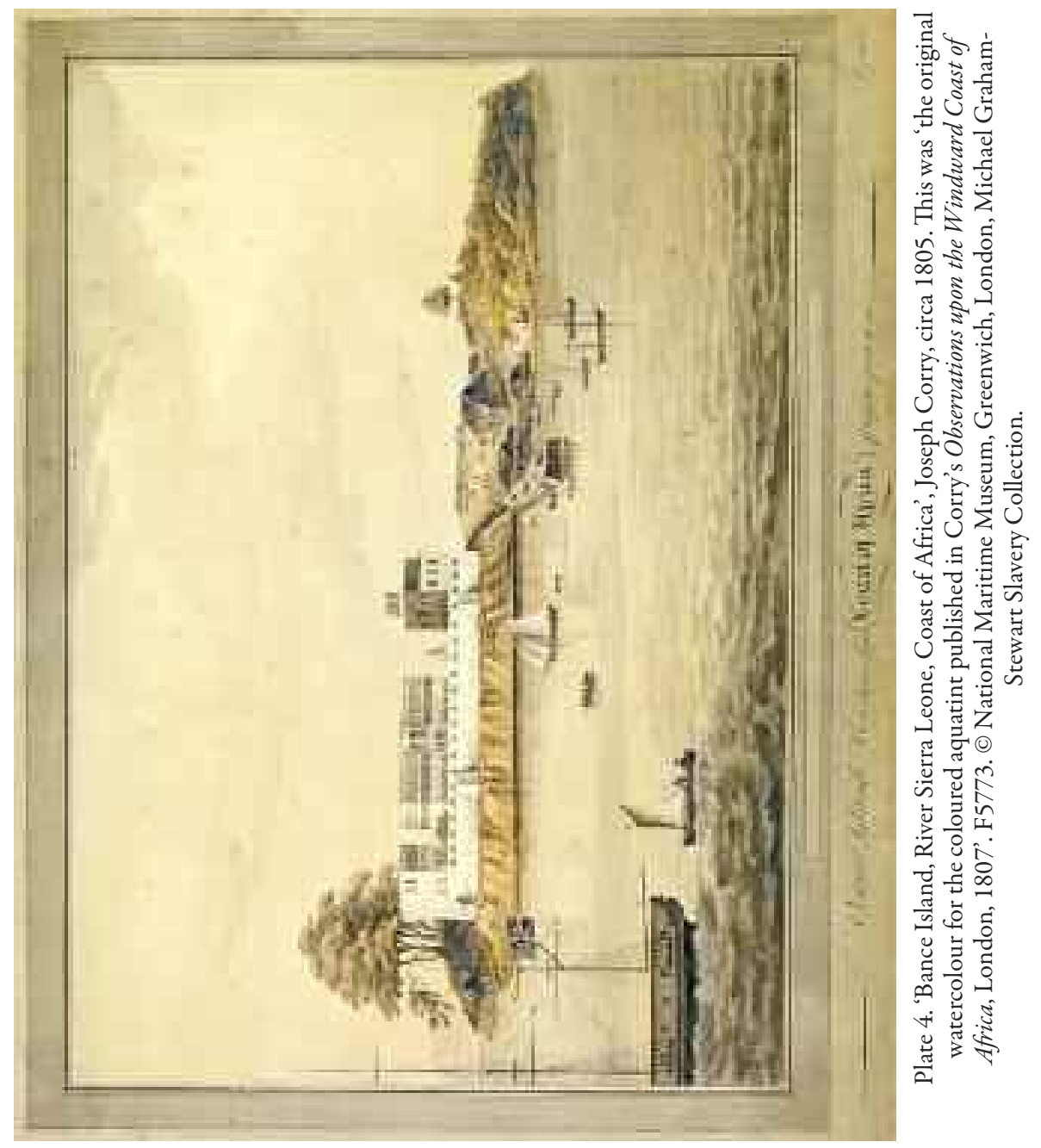




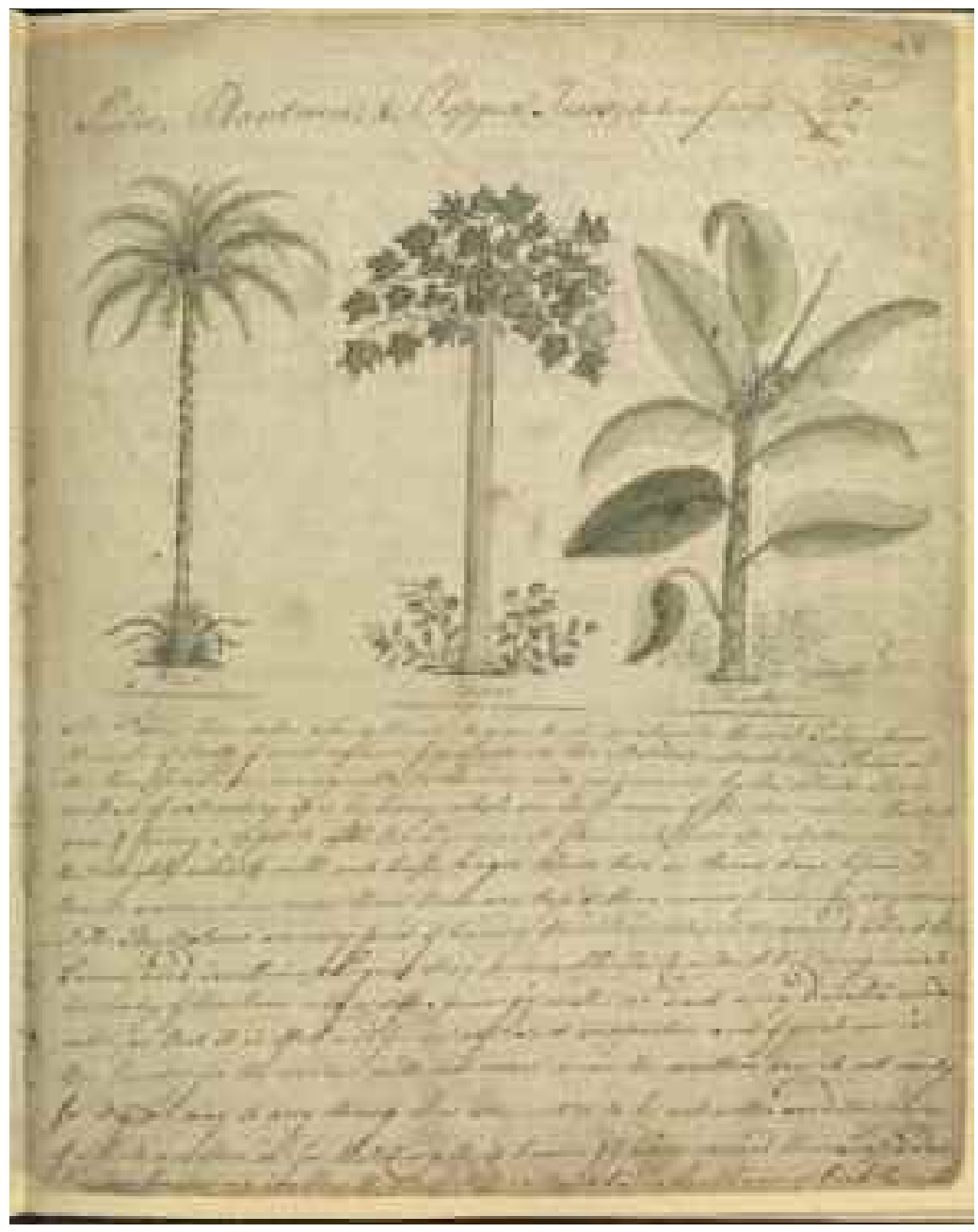

Plate 5. Illustrations of 'Palm, Plantain and Poppa Trees, taken from Life' from the journal of Samuel Gamble, captain of the slave ship Sandown, 1793. L5953.

(c) National Maritime Museum, Greenwich, London. 


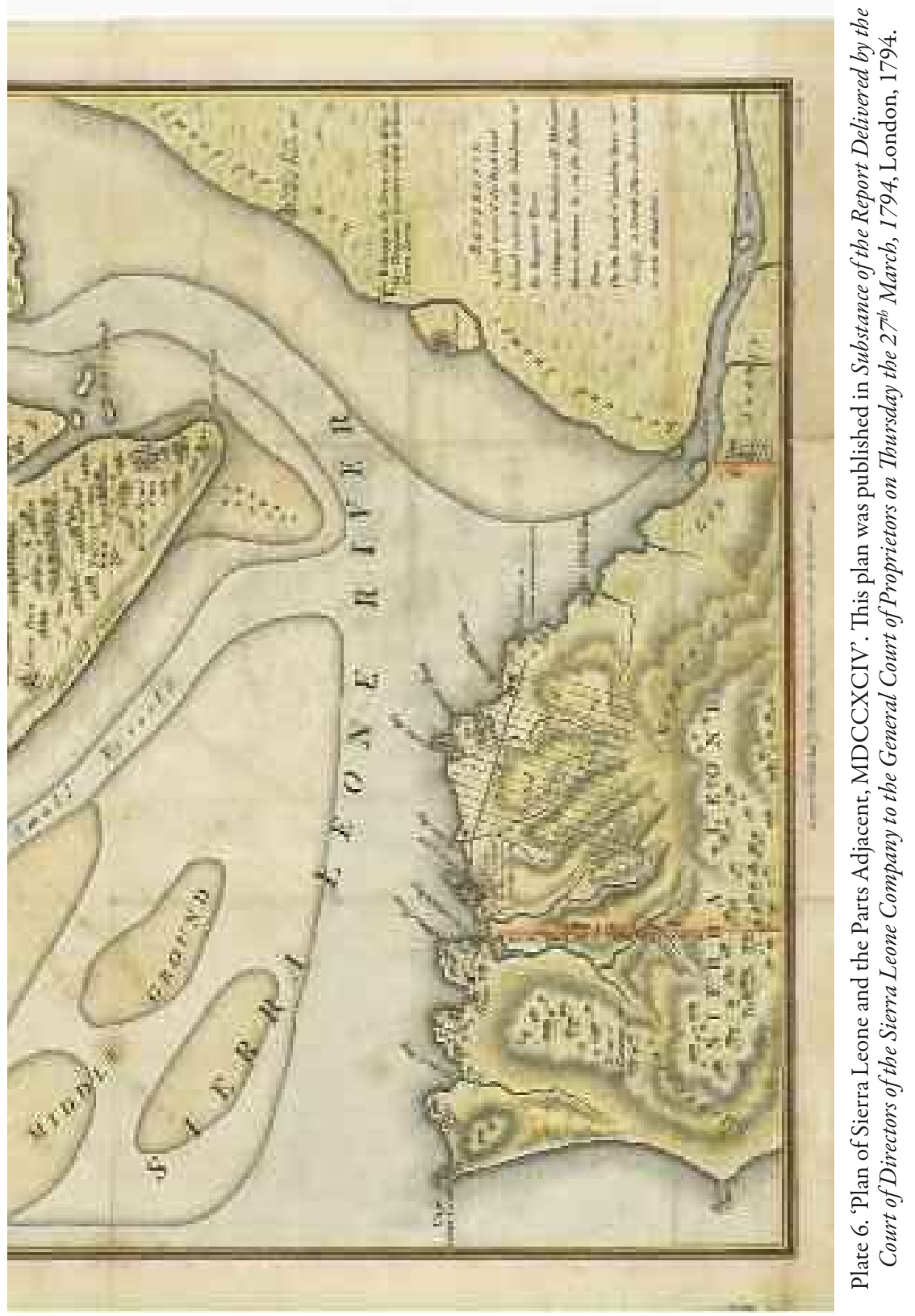




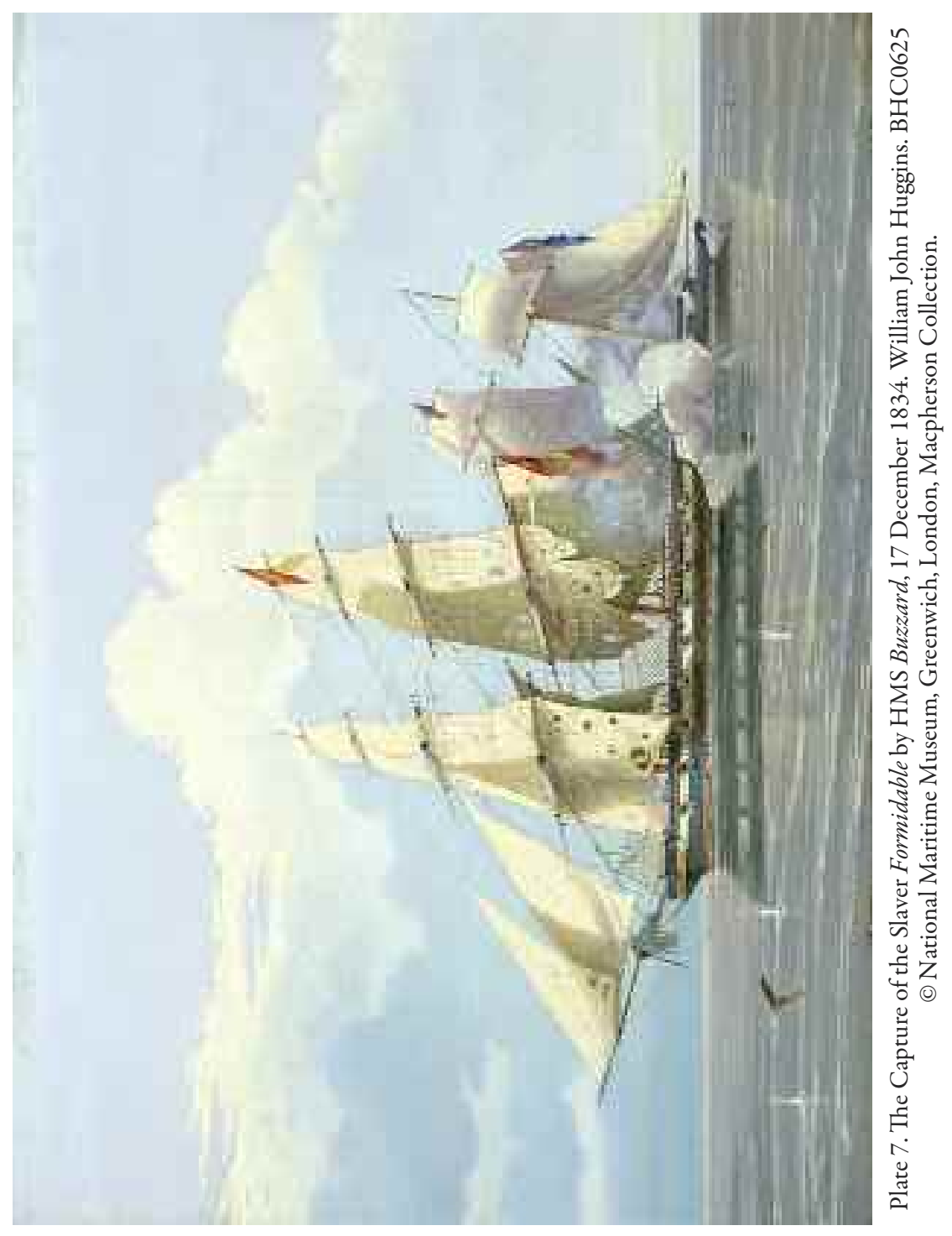




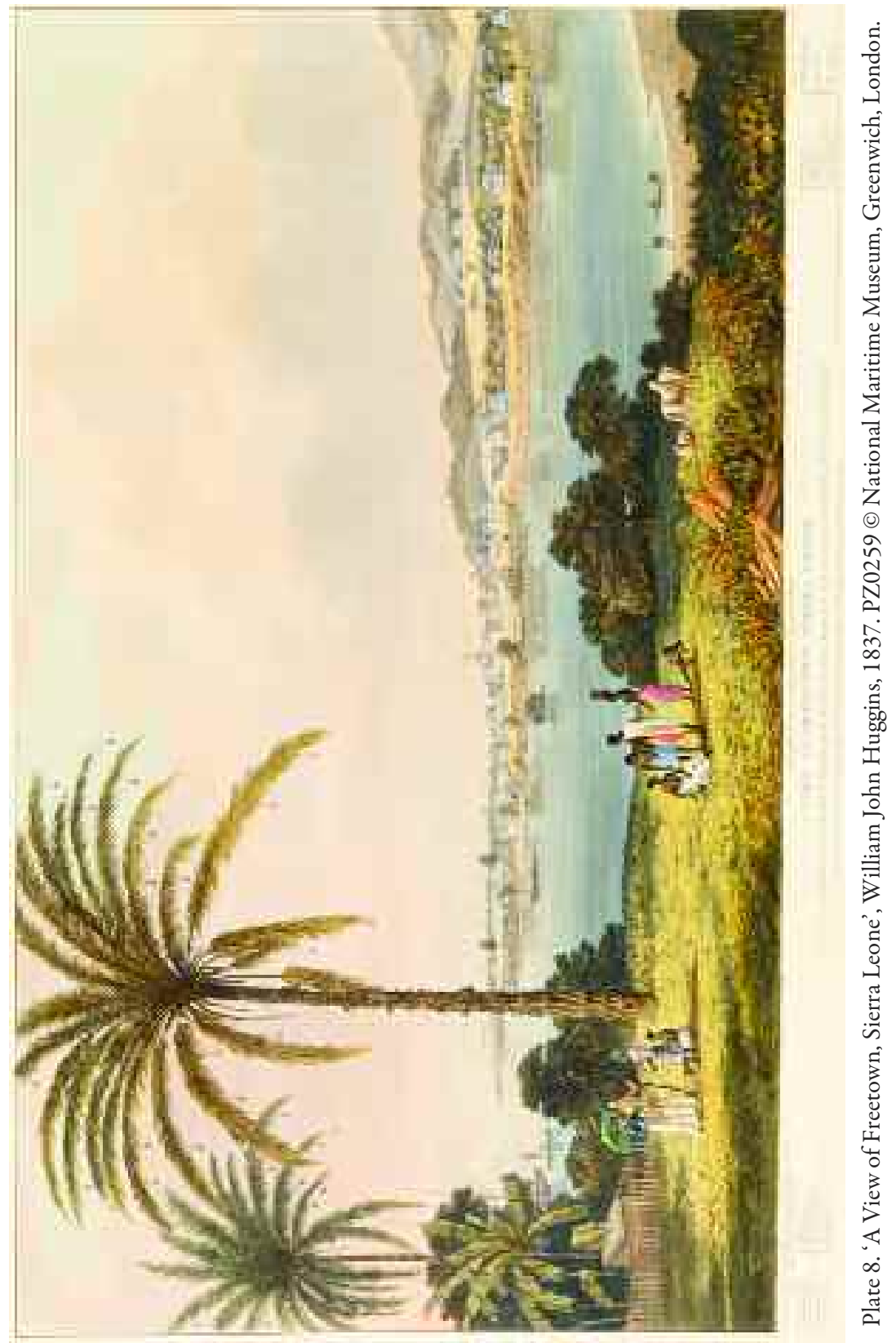


of seeds and plants by the Good Intent, and had reached the conclusion that 'the Western Coast of Africa seems therefore to open a new \& extensive field both for the Curious \& Speculators'. He focused principally on plants he considered 'useful' and was optimistic that his botanical endeavours would be 'beneficial and of utility either to the Mother Country or the Colony'. ${ }^{85}$

In compiling his reports for the Court of Directors, Afzelius scrutinized the claims about crops and cultivation made by Thomas Clarkson in his report to the directors in 1791 and Lieutenant Matthews in his Voyage to the River SierraLeone. Gum was among the export commodities that Clarkson considered would yield 'considerable commercial profits'. Afzelius in response reported that 'of Gums we have a great number of different qualities \& consequently fit for different uses. I shall another Opportunity give full information of all of them, after I shall have explored the Country more accurately .... ${ }^{86} \mathrm{He}$ considered that plants and seeds sent to England in numbered packets on the Amy and the Ocean should be regarded as 'curiosities from an unexplored country, their qualities being not yet discovered'. Other specimens though were 'of known reputation here amongst the Natives, $\&$ in others I have discovered myself some useful property'. Specimen number 41 'sent home alive by the Amy' was 'one kind of Meleguetta Pepper, growing in Sierra Leone'. Specimen number 10 included the 'pods \& seeds of that Indigo plant, which grows most plentifully on this Coast. It is a good sort \& well worth to be turned into use. ${ }^{87}$

Specimen number 7 was described as a 'new species of Coffee, but not having yet had an opportunity of trying its quality, I am not able to tell, whether it is worth any attention or not'. Afzelius was referring to a different species from Arabica, which was the type of coffee cultivated in the West Indies. He later submitted a report in February 1796 providing a 'Botanical Description of a New Species of Coffee', and expressed his hope that the 'discovery of another Species of real Coffee will I hope give real Satisfaction \& be considered as a matter of much importance both to the learned \& commercial World' ${ }^{8}{ }^{8} \mathrm{He}$ reported that 'Such a Coffee has just been found by one our Settlers ... growing on one of the high Mountains of Sierra Leone, in a dry \& gravelly ground'. ${ }^{89} \mathrm{At}$ the start of his report, he summarized the current state of knowledge on different

\footnotetext{
${ }^{85} \mathrm{BL}$, Sierra Leone, 'Mr. Ad. Alfzelius's Report to the Court of Directors of the Sierra Leone Company Respecting Several Natural Productions of Sierra Leone', 4 November 1793, ff. $217 \mathrm{r}-218 \mathrm{r}$.

${ }^{86} \mathrm{BL}$, Sierra Leone, 'Letter Addressed to the Chairman of the Sierra Leone Company', f. 16; 'Mr. Ad. Alfzelius's Report to the Court of Directors', 4 November 1793, f. 229r.

${ }^{87} \mathrm{BL}$, Sierra Leone, 'To the Governor and Council of Sierra Leone. Concerning some Plants and Seeds Sent Home by the Ocean and the Amy', 19 November 1794, ff. 189r, 192v-193v.

${ }^{88}$ BL, Sierra Leone, Adam Afzelius, 'Botanical Description of a New Species of Coffee', February 1796, ff. 197r-200r.

${ }^{89}$ In his journal, Afzelius recorded on Friday 5 February 1796 that, 'To day it was first discovered that there is Coffee growing wild in the mountains of Sierra Leone. Andrew Moore brought this morning Seeds of it to the Governor, saying that he had picked them up on the ground, being occupied in burning some wood, and then looking about him for the tree which had produced these
} 
species of coffee and took into consideration the findings of 'Messrs. Forster Father \& Son' who travelled with Captain Cook on his second voyage to the South Seas. After describing the tree in detail in both Latin and English, he concluded that it was a 'different species from the Arabian ...'. His report was referring to Robusta coffee which was also found in Angola, as it was indigenous to West and West-Central Africa. ${ }^{90}$ In contrast to Arabica coffee which was the type more generally known to consumers in Europe and America, he described how:

The Tree is much larger, the Branches shorter and straighter; the Leaves narrower, more plane, shining only on the underside \& furnished with a longer linear bending point $\&$ underneath with fewer \& less evident glandules, the Stipula differently colored; the Flowers \& all their parts much smaller; the Berries of another shape and lastly the Segments of the Corolla \& the Stamina probably of a different number \&c \&c. ${ }^{91}$

As Lindroth has noted, Afzelius was 'scarcely an explorer-scientist' as he was working in areas that were already familiar to European traders. ${ }^{92}$ In building up his specimen collection, Afzelius travelled out to a number of locations in close proximity to Freetown and further afield. He visited Robana in May 1792, which according to the 'Plan of Sierra Leone and the Parts Adjacent' was located on the southern side of the Sierra Leone estuary in 'low and swampy' ground..$^{93}$ James Strand, the Company Secretary, reported how Afzelius 'has discovered several sorts of dying woods \& Ginger (a species of it) .... ${ }^{94}$ Afzelius later visited the Rio Pongo, located some 140 miles to the north of Freetown, in his search for specimens. ${ }^{95}$ (Plate 5) A journal of his visit to the Banana Islands was lost in the French attack on Freetown in 1794, although several specimens returned on the Amy had been collected there. Afzelius's letters and reports drew

berries, he found one near to him, on which there also were some fruits remaining; but being too ripe and having been so probably for several months, they fell off as soon as he touched the tree'. On the following day, Governor William Dawes, Mr. Witchell and Afzelius set out to locate the source of the coffee. Kup, Adam Afzelius Sierra Leone Journal, pp. 65-6.

${ }^{90}$ I am grateful to Paul Lovejoy for comments supplied in email correspondence. Wild coffee 'was gathered in several parts of Angola' and 'became a favourite crop for developing an alternative economic framework to the slave trade ...' from the early 1820s. Roquinaldo Ferreira, 'Agricultural Enterprise and Unfree Labour in Nineteenth-Century Angola', in Law, Schwarz and Strickrodt, Commercial Agriculture, the Slave Trade \& Slavery in Atlantic Africa, pp. 234-7.

${ }^{91}$ BL, Sierra Leone, Adam Afzelius, 'Botanical Description of a New Species of Coffee', f. 200r.

${ }^{92}$ Lindroth, 'Adam Afzelius: A Swedish Botanist in Sierra Leone', p. 205.

${ }^{93}$ The Company report of 1791 indicated that Robana was 'situated between the English slave factory at Bance Island and the French slave factory at Gambia island. The inhabitants of Robanna, about fifty in number, are fed by King Naimbanna's bounty, and are entirely dependent on him'. Substance of the Report, 1791, p. 13.

${ }^{94}$ Fyfe, History, p. 42; BL, Sierra Leone, 'Mr. James Strands Journal of Occurences from April $21^{\text {st }}$ to Septr $10^{\text {th }} 1792$ ', f. $38 \mathrm{v}$.

${ }^{95}$ Fyfe, History, p. 65; Lindroth, 'Adam Afzelius: A Swedish Botanist in Sierra Leone', pp. 205-6. 
attention to those plants and trees which he considered as profitable for cultivation in the colony, including cinnamon, nutmeg and cocoa. He concluded that the plants 'are not to be found in this Country but must be fetched from another quarter of the world'. Afzelius developed a 'garden of experiment' in Freetown for the cultivation of locally sourced seeds and plants, as well as those imported from other countries including grapevines from Tenerife and apple trees, mulberry trees, potatoes and strawberries from England. ${ }^{96}$ Afzelius was anxious to receive specimens of 'South Sea plants promised from the King's Garden at Kew' for cultivation in Sierra Leone. The dispatch of the plants had been delayed. Henry Thornton had written to Sir Evan Nepean on 30 July 1793 'requesting that application might be made to his Majesty for a few tropical plants from the Royal Gardens at Kew as well as from the Collection brought home by Captain Bligh for the sake of having them carried to the Colony at Sierra Leone'. ${ }^{97}$ Thornton explained that the Company had gone to 'some expence in preparing a Plant Hatch under the direction of Sir Joseph Banks ...' on a ship bound to Sierra Leone. ${ }^{98}$ These plants had been received by 1794 , as the Company directors noted how they had 'succeeded in obtaining several valuable articles of tropical cultivation, through his Majesty's permission, from the royal gardens at Kew, particularly the bread-fruit tree, which will form a very important addition to the Company's collection'. 99

Journeys undertaken by Company employees and settlers were motivated primarily by abolitionist ideology and a desire to spread the benefits of commerce, civilization and Christianity beyond the narrow boundaries of Freetown. Clarkson indicated in very broad terms that Company employees should explore the area to the north-east of Sierra Leone, although Watt's pioneering expedition of 1794 may have been prompted by an invitation from a Fula leader rather than Clarkson's vague instructions. ${ }^{100}$ In order to forge new commercial contacts in slave trading areas, Watt did not take the most direct route to Timbo but followed a more circuitous route which involved travelling 200 miles by boat to the Rio Nunez, then 200 miles overland to Timbo (see Figure 1). On the return journey, he travelled 150 miles overland to Forekaria

\footnotetext{
${ }^{96}$ The Company report of 1794 referred to the 'fencing and cultivating of a garden of experiment ...'. Substance of the Report, 1794, pp. 16, 50; BL, Sierra Leone, 'To the Governor \& Council of Sierra Leone. An Account of the State of the Public Gardens before the arrival of the French and after their departure to the present time', 27 November 1794, ff. 182v-183r.

${ }^{97}$ Sir Joseph Banks played a central role in the development of the 'Exotic Garden' at the Royal Botanical Gardens at Kew. In 1789, Hortus Kewensis indicates that forty-seven species were directly introduced by Banks. The botanical specimens included those collected during Governor Phillip's voyage to Botany Bay and Captain William Bligh's second bread-fruit voyage to Tahiti on the Providence between 1791 and 1793. Carter, Sir Joseph Banks, pp. 96, 241, 248, 278-84.

${ }^{98}$ TNA, CO 267/10, Sierra Leone Original Correspondence, Henry Thornton to Sir Evan Nepean, 30 July 1793, p. 19

${ }^{99}$ Substance of the Report, 1794, p. 50.

${ }^{100}$ Mouser, Journal of James Watt, pp. xiv-xv.
} 
and fifty miles by boat to Freetown. ${ }^{101}$ Whilst at Timbo, Watt began to gather information for an expedition to Timbuktu, a mythical city of wealth and the object of European exploration, but he died before he could undertake the journey. ${ }^{102}$ Returning on 3 May 1794 , Watt expressed a hope that his journal might 'throw light on the state of Africa' and help to 'promote in any shape the humane \& benevolent views of the Sierra Leone Company ...'. Although his journal was not published in full until two centuries later by Bruce L. Mouser, news of his expedition was transmitted relatively quickly to Company shareholders through the directors' reports. ${ }^{103} \mathrm{~A}$ journal kept by Matthew Winterbottom, who accompanied Watt to Timbo, closely informed sections of Dr. Thomas Winterbottom's two-volume An Account of the Native Africans in the Neighbourhood of Sierra Leone published in $1803 .{ }^{104}$

Shorter journeys were undertaken from Freetown to gather information on plants and cultivation, as well as the locations of African traders and the commodities they could supply. A plan of part of the Sierra Leone peninsula and the Bullom Shore, published in the Company report of 1794, indicates how officials on the ground lacked even the most basic information on the names of settlements in close geographical proximity to Freetown. Where the name of the settlement was known this was entered on the plan, as in the case of 'Dick Miller's town' and 'George Dean's town' on the Bullom Shore, but at least nine settlements to the north and west of Freetown were entered simply as 'Native Town' or 'Native Towns' (Plate 6). In the case of a settlement set in 'low and swampy' land on the southern side of the Sierra Leone estuary, there was an attempt to record the local name 'Pulon atot'. To the south-west of Freetown, the plan identifies an unnamed settlement described as 'Town of Runaway Slaves. ${ }^{105}$ In other cases, the plan records intelligence on the status of a settlement and the name of the local African ruler. 'Robagga' set just below 'Pulon atot' was described as 'the Town of the king of the Timmaney [Temne] country which includes Sierra Leone'. Another unnamed town, represented on the plan with a series of eight black dashes, was identified as the 'King of the Bullom Shore's Town which is lately increased'. Settlements are highlighted on the plan as shaded areas with black dashes varying in number from seven to sixteen. ${ }^{106}$ The differing

\footnotetext{
${ }^{101}$ I am grateful to Bruce Mouser for this information supplied in email correspondence.

${ }^{102}$ Mouser, Journal of James Watt, pp. v, xv; Substance of the Report, 1794, p. 143; Fyfe, History, p. 58.

${ }^{103}$ The published Company report of 1794 included a report on the expedition, Substance of the Report, 1794, pp. 134-43.

${ }^{104}$ Dr. Thomas Winterbottom was Matthew Winterbottom's brother. Mouser, Journal of James Watt, pp. v, xv.

${ }^{105}$ Publication of the Company report of 1794 was delayed to enable the inclusion of the map, which had been obtained with the assistance of the Governor of Sierra Leone. 'Plan of Sierra Leone and the Parts Adjacent, MDCCXCIV', in Substance of the Report, 1794, p. 3.

${ }^{106}$ Ibid.
} 
configurations may have been used in a schematic fashion to denote differences in the size and layout of the settlements.

Macaulay made frequent trips to the Bullom Shore on the northern side of the Sierra Leone estuary to check on the progress of sugar cultivation at Watt's plantation, although he found that the canes had been devoured by ants which marched 'in large armies closely compacted .... ${ }^{107}$ James Watt and James Strand appeared disappointed with the outcome of a visit to the Banana Islands, located off the southern tip of the Sierra Leone peninsula, in April 1792. They observed that 'these Islands have always been described as paradises', but found the soil to be 'poor \& indifferent'. ${ }^{108}$ John Gray, the Company accountant, and James Watt both kept detailed journals of a visit to Furry Cannaba's town in February 1795, located to the south-east of Freetown. This two-week journey, undertaken in response to instructions from Macaulay, was intended to establish the extent of trade in camwood, ivory and bullocks that could be secured with the Muslim Mandinka ruler through a factory in the Kamaranka River located to the southeast of Freetown in Yawry Bay ${ }^{109}$ Gray attempted to assess whether camwood could form an independent trade with the Company 'when the inhuman Traffic in Men is abolished .... In assessing the outcome of their journey, Gray considered that they had succeeded in gaining 'some little knowledge of the Country $\&$ of the people, which we were before ignorant of .... He thought that the intelligence gathered on camwood cultivation was particularly valuable, as the fact that 'it is a wood \& grows on the Continent of Africa seems to comprehend the sum total of European knowledge relating to it'. ${ }^{110}$

Reflecting on the nature of his journal-writing, Gray considered that the barren countryside through which they passed provided no scope for 'either picturesque description, or home spun relation', but felt nonetheless that a journal 'rich in regard to soil \& local circumstances, is knowledge which pays for every step the wearied Traveller takes'. There are, nonetheless, some sections which evoke vivid images including their night-time canoe journeys along rivers where they complained how their 'ears were frequently annoyed by the hollow growling of Aligators ...'. In addition to the usual type of Eurocentric comments on exotic features of the landscape and peoples they observed, Gray and Watt gathered intelligence on African slave suppliers and modes of enslavement. It was noted how Furry Cannaba, a man aged between sixty and seventy, could arrange within a few days to have fifty to one hundred slaves supplied from headmen in different towns and Watt, drawing on knowledge gained from his

${ }^{107}$ Suzanne Schwarz, ed., Zachary Macaulay and the Development of the Sierra Leone Company, 1793-4: 1. Journal, June-October 1793, Leipzig, University of Leipzig Papers on Africa, History and Culture, series no. 4, 2000, p. 66; Substance of the Report, 1794, p. 49.

${ }^{108}$ BL, Sierra Leone, 'Mr. James Strands Journal of Occurrences', f. $34 v$.

${ }^{109}$ Fyfe, History, p. 58.

${ }^{110} \mathrm{BL}$, Sierra Leone, 'Mr. Grays Journal in January \& February 1795 to \& from Furry Cannaba', ff. 42r-60r. 
earlier travels to Fuuta Jalon, made comparisons between modes of transporting goods by caravan (Plate 2). ${ }^{11}$

Macaulay also undertook regular short journeys from Freetown to establish trading relations and persuade influential headmen to give permission for a factory to gather African produce, whilst also accommodating a missionary or schoolmaster. As a new entrant to trade on the coast, the Company lacked the type of social capital accumulated by slave captains in their dealings with African and Eurafrican merchants. During a journey to 'the Bananas and Sherbro' in the Ocean in July 1793, Macaulay met William Ado at Jenkins Town on the northeastern corner of Sherbro Island. He explained that the motive of his visit was 'to acquaint myself with him and the other chiefs, to form connections with them, to pay the customs, to fix factories on a sure footing, to adjust differences and to give them a thorough knowledge of the views and intentions of the Sierra Leone Company'. Next day, Macaulay invited this 'active, sensible and vivacious man' whom he thought was aged about ninety to dine on board the Ocean and reported how 'we talked much of the settlement and the Company's views, which he listened to with seeming satisfaction', although Macaulay's assessment needs to be treated with some scepticism as he was reporting to his employer and patron and might have presented on overly optimistic picture. ${ }^{112}$

Expanding the Company's view of trade beyond the immediate hinterland of Freetown depended on gathering intelligence about African traders and their preferences in order that they could compete with slave captains for export commodities. A journal kept during a voyage to West-Central Africa on board the Company ship Calypso between 17 June and 29 December 1796 contains a wealth of information on traders and goods along the coast. Whilst moored in the River Gabon, E. L. Parfitt, supercargo, noted how he 'dash'd ... and saluted with $4 \mathrm{Guns}^{\text {'113 }}$ the various headmen with whom he planned to conduct trade, including Qua Ben, King Glass, King Cringee, Governor Will and Prince William Henry of Sandy Point. ${ }^{114}$ Of King Cringee, he noted that he was 'as honest as the best but he does not appear to command much Trade'. In relation to Governor Will, Parfitt considered that he 'is to be trusted a little', but 'he is a very Drunken fellow. ${ }^{115}$ Although principally a trading journal, Parfitt included observations on topographical features, as well as points of interest and curiosity

${ }^{111}$ BL, Sierra Leone, 'Mr. Grays Journal', ff. 55v, 57r, 58r; 'Mr. Watts Journal to Furry Cannabas between the $31^{\text {st }}$ January $\& 11^{\text {th }}$ February $1795^{\prime}$, ff. 63r-85v.

${ }^{112}$ An account of this meeting was included in the directors' report to shareholders in 1794. Schwarz, Zachary Macaulay and the Development of the Sierra Leone Company, 1793-4: 1. Journal, June-October 1793, pp. 26-9; Substance of the Report, 1794, pp. 131-2.

${ }^{113} \mathrm{~A}$ 'dash' refers to a gift used to open trade with African merchants and traders.

${ }^{114}$ BL, Sierra Leone, 'Extract of a Diary kept by E. L. Parfitt on board the Sierra Leone Companys Ship Calypso, William Cole Master from the River Sierra Leone to the River Gaboon \& back commencing the $17^{\text {th }}$ June $\&$ terminating the $29^{\text {th }}$ December 1796 ', ff. 133r-156r.

${ }^{115}$ BL, Sierra Leone, 'Mr. Parfitts Information Respecting Trade Between Sierra Leone \& Cape Lopaz, including the Islands St. Thomas \&c.', f. 118v. 
about the people he observed. He was clearly fascinated with 'Qua Bens Queen' who wore ten 'large $\&$ heavy Brass Trade Manillas' on her right arm and eight on her left, and 'on each leg 41 Copper $\&$ Brass rings fitting tight', a practice which he noted 'frequently occasion sores'. ${ }^{116}$

Two short journals describing travel around the Sierra Leone peninsula in April 1798 by some of the Nova Scotian settlers are very different in tone and content to the accounts written by Company officials, and they reflect relatively little concern with notions of commerce, civilization and Christianity. ${ }^{117}$ Although the journals include some comments on the course of rivers, the quality of the soil and the location of wild coffee (i.e. Robusta), the major emphasis in these accounts was on taking in the scenery from the hills above Freetown where they could see as far as Cape Shilling and the Banana Islands. The excursion had the feel of a hunting trip, and it was recorded on 18 April 1798 how Abraham Hazeley 'shot a very large Eagle whose wings spread about 6 feet' and 'weighed about 12 pounds'. Richard Crankapone, who later died defending the colony during an attack by King Tom in 1801, was among the group of Nova Scotian settlers who ascended the hills above Freetown and proceeded to follow the course of a number of brooks, before returning four days later. ${ }^{118}$ They travelled in a mainly southerly direction, and after three and half days reached the 'back of the Sugar loaf mountain'. ${ }^{119}$ The second excursion around the peninsula took three days, and in each case the men never travelled far enough away from Freetown to miss the sound of a gun fired from Thornton Hill morning and evening. ${ }^{120}$ Abraham Hazeley and Thomas Wilson, two of the Nova Scotians who took part in these excursions, later accompanied Alexander Smith on a voyage to the River Kissi in 1802 to arrest Nathaniel Wansey and Daniel Carey who had played a leading role in the rebellion against the Company in $1800 .{ }^{121}$

Reports of travel on the upper Guinea coast sparked new interest in the prospects of Christian conversion among the peoples encountered and described in reports sent home. A copy of Watt's journal was sent to the newly-formed interdenominational Missionary Society (later renamed the London Missionary Society) and, in the context of growing millennial expectation, this convinced

${ }^{116}$ Ibid., f. 151v.

${ }^{117}$ These journals predate by sixty years the travel accounts of 'three pioneering Americo-Liberians who were inspired to live and travel into the far interior: James Sims, George Seymour, and Benjamin Anderson'. James Fairhead, Tim Geysbeek, Svend E. Holsoe, Melissa Leach, eds, African American Exploration in West Africa. Four Nineteenth-Century Diaries, Bloomington, IN, 2003, p. 1.

${ }^{118}$ Fyfe, 'Our Children Free and Happy', p. 72.

${ }^{119}$ In a description of the colony in 1863, Robert Clarke noted how 'the "Sugar Loaf", the highest mountain in the colony, is wooded to its summit'. Robert Clarke, 'Sketches of the Colony of Sierra Leone and its Inhabitants', Transactions of the Ethnological Society of London, Vol. 2, 1863, p. 321.

${ }^{120} \mathrm{BL}$, Sierra Leone, 'Journal Kept by Mr. Hermitage during Two Excursions undertaken for the Purpose of Exploring the Peninsula of Sierra Leone', ff. 25r-33v.

${ }^{121}$ Bruce L. Mouser, ed., Guinea Journals. Journeys into Guinea-Conakry during the Sierra Leone Phase, 1800-1821, Washington, 1979, pp. 12-13, 115-36. 
the directors that the gospel could be introduced into 'Africa, that much-injured country'. The Evangelical Magazine for December 1796 carried a lengthy report on Watt's expedition, including references to the landscape, economy and culture of the areas through which he travelled. In their appeal for missionary candidates, readers were assured that the 'climate of the Foulah Country' was 'more congenial to European constitutions than that on the coast', and that 'the people of Teembo' had expressed 'a desire to have Europeans settle among them, with a view to be improved in the knowledge of agriculture and the mechanic arts'. Although the article mentioned that the 'professed religion of the country is Mahometanism', the directors of the Missionary Society appeared not to view this as an obstacle to Christian conversion. ${ }^{122}$ This impression was no doubt based on Watt's journal, as shortly after leaving Timbo he recorded how 'it would appear to me no hard matter to overturn the empire of Mahommed in this Country, if the King \& a few chiefs were gained over, and the law abolished which compels people to pray on pain of death, the business would be done'. ${ }^{123}$ In reality though, Christian missions in Africa had virtually no success in converting Muslims, as distinct from 'pagans'.

News of Watt's expedition spread rapidly in missionary circles, even before the article appeared. The prospect of converting Muslim Fula to Christianity inspired the Methodist evangelist Thomas Coke to organize a mission based on Moravian principles of sending out skilled lay artisans with a preacher. After just a brief stay in Freetown in 1796 this missionary group returned home, and Governor Macaulay's scathing denunciation of their lack of preparedness highlights the gulf between enthusiastic travel accounts disseminated in Britain and the reality of African conditions. ${ }^{124}$ Four years earlier and perhaps after reading the directors' first published report, the Reverend Melvill Horne imagined from his parish at Madeley in Shropshire that he could use his experience of Methodist itinerancy to travel out among the Temne and convert them to Christianity. He explained that he was leaving his parish to 'encounter all I esteem dreadful in life' so that 'the wretched sons of bleeding Africa may be brought to flee for sanctuary under the wings of the God of Israel'. Once at Freetown, he planned 'to go farther into the Country among the Natives build myself a hut, and try what living among them will do'. Drawing on Scriptural references from Daniel 3, as well as imagery from the blast furnaces of Coalbrookdale, Horne asked his parishioners to pray for his safe passage "through the burning-fiery furnace which may perhaps await me there'. ${ }^{125} \mathrm{He}$ was, not

122 'An Address from the Directors of the Missionary Society', The Evangelical Magazine, December 1796, pp. 493-503.

${ }^{123}$ Mouser, Journal of James Watt, p. 63.

${ }^{124}$ Fyfe, History, pp. 67-8.

${ }^{125}$ Melvill Horne, Letters from the Rev. Melvill Horne late Curate of Madeley, Salop; Now Missionary at Sierra Leone, Africa, to his Friends at Madeley, Previous to his Departure from England, Madeley, 1792, p. 25. 
surprisingly, a dismal failure as a missionary, travelling out no further than a few miles from Freetown and preaching only one sermon to Africans. Returning home after just fourteen months, he still advised prospective missionaries to itinerate from village to village, live among local peoples and cultivate their lands, but his account of his failed mission, published in 1794 and still read in British and American missionary circles in the 1820 s, provided scant information on African culture and society. ${ }^{126}$

\section{IV}

One of the Company shareholders listed in 1792 was Prince Naimbanna, the son of King Naimbanna of the Koya Temne, who was taken to England for a period of education with the intention that he would return to convince his countrymen of the benefits of Christianity. ${ }^{127}$ These hopes were dashed as the so-called 'Black Prince' died on the return journey to Sierra Leone in July 1793, and a 'Sketch' of his life in The Evangelical Magazine lamented the loss of 'this amiable and enlightened African, from whose exertions, had he lived, not only the Company might have derived important services; but, under his government, Christianity might have found a fostering friend'. ${ }^{128}$ Although Macaulay reported in his journal that Henry Granville Naimbanna had penned a deathbed will testifying to the 'worthy' aims of the Company, this cannot be taken as a typical African response as Naimbanna had spent over a year resident in England under the influence of Henry Thornton and Granville Sharp, as his new Christian names indicate. ${ }^{129}$

Overall, the evidence indicates that African leaders among the Temne, Bullom, Susu and Fula remained unconvinced by the Company's formula for

${ }^{126}$ Melvill Horne, Letters on Missions Addressed to the Protestant Ministers of the British Churches, Bristol, 1794.

${ }^{127}$ H. A. Rydings, 'Prince Naimbanna in England', Sierra Leone Studies, New Series, 8, June 1957, pp. 200-208.

128 'Sketch of the Life of John Henry Naimbanna, an African Prince', The Evangelical Magazine, December 1795, pp. 481-6. The Black Prince. A True Story, Being an Account of the Life and Death of Naimbanna, An African King's Son was first published in the Cheap Repository Tract series. The pamphlet included reference to how 'numberless were the plans which he formed for the purpose of spreading the light of the gospel among his rude countrymen .... This was clearly based on a section contained in Zachary Macaulay's Sierra Leone journal on 18 July 1793. Macaulay recorded how 'Numberless were the plans he amused himself with devising for the purpose of spreading the Gospel and opening the eyes of his rude countrymen .... Another edition of the pamphlet was published to support the anti-slavery campaigning of the Birmingham Female Society in 1828. This version included the addition of a poem entitled 'The Negro Boy and Watch', which was based on an anecdote related to the life of Prince Naimbanna. 'The Black Prince. A True Story, Being an Account of the Life and Death of Naimbanna, An African King's Son', Cheap Repository Shorter Tracts, A New Edition, London, 1800, pp. 326-41; The Black Prince, A True Story, Being an Account of the Life and Death of Naimbanna, An African King's Son, Birmingham, 1828; Schwarz, Zachary Macaulay and the Development of the Sierra Leone Company, 1793-4: 1. Journal, June-October 1793, p. 30

${ }^{129}$ Schwarz, ibid., p. 30. 
economic reform and, as in other areas of Africa, were uncomprehending of or hostile to the abolitionist message. ${ }^{130}$ The Fuuta Jalon responses to Watt constituted an outright rejection of the Company's antislavery ideas if not their trading plans. ${ }^{131}$ Attempts to divert the trade of Fula caravans from Fuuta Jalon along a new path to Freetown through the Rio Pongo encountered a hostile response. Slave traders in the Rio Pongo, fearing an interruption to supplies, refused to deal with Fula caravans supplying ivory, rice and camwood to the Company's factory at Tooka Kerren or Freeport, and the murder of a Fula caravan leader closed the path and interrupted the emerging trade in ivory. A number of Eurafrican and European slave traders opposed Company attempts to control the river's commerce between 1795 and 1802, as this anti-slavery presence in the Rio Pongo reflected a direct attempt to raise prices for essential trade goods and prevent traders from purchasing slaves. ${ }^{132}$

Company plans for cultivation also encountered resistance. African labour was withdrawn from the Company's plantation on the Bullom Shore in a dispute over wage levels in 1793, although Company officials explained the failure of sugar cultivation by resorting to stereotypical images of African indolence and laziness of the type used by Lieutenant Matthews. ${ }^{133} \mathrm{An}$ antagonistic relationship with African labour is suggested by the Company's admission that bringing in former slave overseers from the West Indies to manage the new plantations was an error of judgement, as well as in Isaac Dubois's reference to Watt having 'a serious Palaver with his People .... . ${ }^{134}$

African traders did respond to new commercial opportunities created by the growth of Freetown, but as a supplement to slave trading and not as a replacement. Furry Cannaba pointed out to Watt and Gray on several occasions in February 1795 that he had 'built the Town in which we now are $\&$ the other adjoining for the purpose of carrying on trade with the S. Leone Company'. ${ }^{135}$ Company officials did not attempt to exclude African slave traders from the

\footnotetext{
${ }^{130}$ Parfitt, for example, warned Company traders how it would be dangerous for a White person that is unconnected with the slave trade to press the abolition in conversation with the Blacks at such places as Bonny \& the Callabars ...'. BL, Sierra Leone, 'Mr. Parfitts Information Respecting Trade Between Sierra Leone and Cape Lopaz, including the Islands of St. Thomas \&c.', ff. 129v-130r.

${ }^{131}$ When Watt chastised Omar, a headman, for offending the God to whom he prayed five times a day, he rebuffed Watt's argument by saying how 'the people with whom we go to war ... "do not pray to God. We never go to war with people who do God Almighty service”.' Mouser, Journal of James Watt, p. 44.

${ }^{132}$ Bruce L. Mouser, 'Trade, Coasters, and Conflict in the Rio Pongo from 1790 to 1808', Journal of African History, XIV, 1, 1973, pp. 45-64 (55-64); Mouser, 'Continuing British Influence', pp. 766-9; Mouser, Journal of James Watt, pp. xii, xvi.

${ }^{133}$ Substance of the Report Delivered by the Court of Directors of the Sierra Leone Company, to the General Court of Proprietors, on Thursday the 29th March, 1804, London, 1804, p. 12.

${ }^{134}$ Christopher Fyfe, ed., Anna Maria Falconbridge: Narrative of Two Voyages to the River Sierra Leone during the Years 1791-1792-1793 and the Journal of Isaac DuBois with Alexander Falconbridge. An Account of the Slave Trade on the Coast of Africa, Liverpool, 2000, p. 181.

${ }^{135}$ BL, Sierra Leone, 'Mr. Grays Journal', f. 54r.
} 
colony, as they were dependent on them for food supplies and saw their presence in Freetown as an opportunity to win hearts and minds. ${ }^{136}$ When John Pearce, an 'eminent' slave trader of Nalu descent in the Rio Nunez visited Freetown in August 1797, Macaulay recognized that in order to 'detach him from the slave trade' he would need to make him an attractive proposition for an alternative form of profit. He resolved that the way to do this was to arrange for Pearce to build a salt house for the Company at his place whereby we should be able thro his medium to engross most of the ivory trade of that river. ${ }^{137}$

African traders moved in and out of Freetown on a regular basis, with the Company estimating in 1804 that 'one to two hundred natives visited the Settlement every day for the sake chiefly of exchanging articles of African produce for British manufactures'. ${ }^{138}$ There was also a significant African presence in the colony according to a census taken in 1802. In addition to 891 Nova Scotian settlers, 515 Jamaican Maroons and twenty-seven Europeans, the census identified a number of Africans resident in settlers' households, as well as ninety Kru from Liberia, and fifty-eight inhabitants described as 'Dalla Moodoos People'. ${ }^{139}$ Almamy Dalu Muhammadu Dumbuya (also known as Dala Modu) had established a village named Dalamodiya adjacent to Freetown in 1794. Dala Modu's presence at Freetown provided a direct link to Muslim trading networks in the Rio Nunez and Rio Pongo to the north of Freetown and the "caravan commerce that linked Freetown to that of Fuuta Jaloo and the Niger River system'. ${ }^{140}$

Trade opened up opportunities for social encounter between women drawn from different cultures. In 1796, Macaulay recorded how 'A Lady of the name of Aredyana, the wife of the Port Logo [Loko] chief Namina modou' had been in Freetown for several days as 'she had come with her Husband's rice \&c to market' and 'brought with her a boy $\&$ a girl whom she left to be educated "white man's fashion"'. ${ }^{141}$ Betsey Walker, a Nova Scotian, managed a slave factory at Crawford's Island and Nova Scotian and Jamaican Maroon women used huckstering skills developed in their former lives in the Americas to trade inside and outside the colony. ${ }^{142}$ Settler women from Freetown, including the Nova

\footnotetext{
${ }^{136}$ Watt and Gray passed through two towns belonging to William Cleveland en route to Furry Cannaba's town. They noted how one of these towns, Appullungwa, was a 'slave town' where women and children were engaged in rice cultivation, and it is likely that these areas supplied food to Freetown throughout the Company's period on the coast. BL, Sierra Leone, 'Mr. Grays Journal', ff. 44r, 45v.

${ }^{137}$ Huntington Library, MY418(22), Journal of Zachary Macaulay, June 1797-January 1798, 10 August 1797.

${ }_{138}^{13}$ Substance of the Report, 1804, p. 8.

${ }^{139}$ TNA, WO1/352, War Department In-Letters and Papers, iv, Sierra Leone: Sierra Leone Company.

${ }^{140}$ Bruce L. Mouser, 'Alimaami Dalu Muhammadu Dumbuya: Trial of a Slave Trader', draft chapter supplied in email correspondence.

${ }^{141}$ Huntington Library, MY418(13), Zachary Macaulay's journal, 26 July-26 September 1796, p. 4 .

${ }^{142}$ F. B. Spilsbury, Account of a Voyage to the Western Coast of Africa, London, 1807, pp. 11, 14.
} 
Scotian shopkeeper and preacher Mary Perth, travelled to Pa Demba's town in the Temne country to witness the trial of Hanna, the wife of Robin Dick. ${ }^{143}$ Conversely, when Betsey Heard, a mulatto slave trader, visited Freetown she transmitted African cultural understanding of diseases and medicine to Thomas Winterbottom, the Company doctor, which he subsequently incorporated into his Account of the Native Africans in the Neighbourhood of Sierra Leone. ${ }^{144}$

The advantages to be gained from a western education in the colony were certainly recognized by neighbouring Africans, but this did not imply acceptance of Company principles. From the Company perspective, the influx of pupils was seen as evidence of the responsiveness of Africans to the Company's message. The motivation for attendance at colony schools, however, is likely to have had more in common with the long-standing practice of élite Africans sending their children for education with slaving merchants in England. ${ }^{145}$ Disputes with parents led to the withdrawal of children from school on a number of occasions, which may have reflected a rejection of the Company's emphasis on Christian teaching and a desire, as in a number of documented cases in Nigeria, for secular education. ${ }^{146}$

African responses to the early preaching attempts of Melvill Horne were characterized by indifference. When the inhabitants of Signor Domingo's town at Royema, four miles east of Freetown, gathered to hear Horne's sermon on 'We Preach Christ Crucified' delivered through an interpreter in 1793, Isaac DuBois noted that he 'did not make much impression on them' whilst Anna Maria Falconbridge, considered his efforts 'preposterous'. ${ }^{147}$ The choice of Royema for Horne's one sermon was most likely informed by the fact that Signor Domingo regarded himself as Catholic, and periodically attended Anglican worship in the Company's church. ${ }^{148}$ The missionary efforts of Boston King, a black Methodist Huntingdonian preacher, would in all likelihood have received a similar response on the Bullom Shore, as he would have been regarded as 'white' at least in a cultural sense. Africans behaving as white men were characterized as oporto (meaning 'white') among the Temne, just as western-educated Africans including Saros and Brazilian repatriates were referred to as oyinbo in Yoruba and yovo in Dahomey in the nineteenth century. ${ }^{149}$

${ }^{143}$ Kup, Adam Afzelius Sierra Leone Journal, p. 63.

${ }^{144}$ Fyfe, History, pp. 64-5.

${ }^{145}$ Curtin, Image of Africa, p. 14; Mouser, 'Trade, Coasters and Conflict in the Rio Pongo', pp. 52-5, 63 .

${ }^{146}$ J. F. Ade Ajayi, Christian Missions in Nigeria 1841-1891. The Making of a New Élite, London, 1965, p. 133; E. A. Ayandele, The Missionary Impact on Modern Nigeria 1842-1914, London, 1966, p. 81.

${ }^{147}$ Fyfe, Anna Maria Falconbridge, pp. 110, 178. Horne set out that 'this good God loves black men as well as white men'. 'A Sermon by the Rev. Mr. Melvill Horne', Baptist Annual Register, September 1795, pp. 249-55.

${ }^{148}$ Schwarz, Zachary Macaulay and the Development of the Sierra Leone Company, 1793-4: 1. Journal, June-October 1793, pp. 10-11.

${ }^{149}$ I am grateful to Magbaily Fyle and Robin Law for this information contained in email correspondence. 
The Company's intervention on the Sierra Leone peninsula was disruptive, and led to sustained conflict over land tenure and sovereignty. It was assumed by the Company that the land on which the settlement was based had actually been purchased under the terms of a treaty of 1788 , but they failed to comprehend the cultural complexities that underpinned the landlord-stranger relationship and the need to renegotiate what was really a lease of land in the circumstances. ${ }^{150}$ Frequent lengthy palavers instigated by local African rulers point to the continuing dissatisfaction on this issue, as does the willingness of Temne to join forces against the Company in a rebellion by Nova Scotian settlers in 1800. In 1793, Macaulay noted how 'Some people have been busily employed in filling their heads with an idea that we mean to subjugate the whole country'. In the following year, the Company directors referred to the persistence of rumours that the Sierra Leone Company intended to 'usurp the power of the chiefs, and, in the end, to drive them from their own territory .... ${ }^{151}$ Macaulay and Wilberforce blamed European and American slave traders on the coast for deliberately stirring up trouble among neighbouring Africans and obstructing the Company's views. Wilberforce considered that they orchestrated 'a general concert of the natives against us ... and obstructed our confidential intercourse with the natives'. ${ }^{152}$ However, Magbaily Fyle notes how anxieties about encroachment were deep rooted, and the construction of military defences at Fort Thornton created fears of domination by the beginning of the nineteenth century. This is reflected in comments made by Thomas Ludlam shortly after the transfer of the colony to Crown control in January 1808. He claimed that 'our nearest neighbours, who some years ago twice attacked the colony and with whom peace was not concluded till last July, are now on the most friendly terms with us'. Yet, these terms were imposed through force. Ludlam pointed out that the Colony's influence had increased as a result of 'our success in the last mentioned warfare' and the 'erection of permanent fortifications' had 'rendered us formidable in the eyes of our neighbours. ${ }^{153}$ Following the imposition of a new treaty, the Temne lost virtually all of their land on the peninsula and the British subsequently 'claimed the land by right of conquest'. ${ }^{154}$

The practice of escaped slaves seeking asylum in the colony antagonized local rulers. At an early stage, it appears that Freetown had developed a reputation as

${ }^{150}$ C. Magbaily Fyle, Nationalist History of Sierra Leone, Freetown, 2011, pp. 47-8; Christopher Fyfe, 'Freed Slave Colonies in West Africa', in John E. Flint ed., The Cambridge History of Africa, vol. 5, from c. 1790 to c. 1870 , Cambridge, 1976, pp. 170, 175, 178.

${ }^{151}$ Schwarz, Zachary Macaulay and the Development of the Sierra Leone Company, 1793-4: 1. Journal, June-October 1793, p. 37; Substance of the Report, 1794, p. 125.

${ }^{152}$ Bodleian Library, University of Oxford, William Wilberforce Family Papers, c.52, ff. 30-31.

${ }^{153}$ University of Illinois, Chicago, 'Observations (by Mr. Ludlam) Respecting the Relations of the Colony with the Neighbouring Countries', Sierra Leone, 1 May 1808.

${ }^{154}$ Magbaily Fyle, Nationalist History, p. 48; Fyfe, 'Freed Slave Colonies in West Africa', p. 179; Curtin, Image of Africa, p. 136. 
a place of asylum even though the colony's powers were very limited. ${ }^{155}$ An enslaved African woman who encountered Macaulay on a ship at the Îles de Los in February 1795 had the impression that he could redeem her. In a letter to his sister, Macaulay reported how this woman, who had been sold to pay off gambling debts incurred by her husband, pleaded with Macaulay to release her. He disembarked after struggling to find some well-meaning but empty words to reassure her about her fate with a 'kind master' in the Americas. ${ }^{156}$

After sixteen years of intervention, the Company's policies of attempting to persuade Africans in the hinterland of Sierra Leone to relinquish the slave trade in favour of cultivation and the exchange of agricultural goods had failed. There was no diminution in slave trading attributable to African acceptance of Company ideas. British and American ships continued to pass close to Freetown as they sailed from the slave fort at Bunce Island, the Bullom Shore and the Banana Islands. Lacking political authority for direct intervention and with limited military resources, Governor Macaulay and his successors William Dawes and Thomas Ludlam were powerless to halt the outward flow of enslaved Africans throughout the period of the Company's activity in Sierra Leone between 1791 and 1807 .

After 1808, circumstances changed markedly when Sierra Leone became a Crown Colony and as Britain adopted a proactive role in the international abolition of the slave trade. Royal Navy patrols were stationed at Freetown to intercept illegal slaving vessels (Plate 7), and over the next six decades the implementation of suppression policies led to the forced inward migration of an estimated 100,000 recaptives or Liberated Africans. ${ }^{157}$ The earliest recaptures were mainly made near to Freetown, as illustrated in the cases of the São Domingos and São Joaquim intercepted by Captain Frederick Parker of HMS Derwent in November 1808. Gomez, the captain, testified that he had bought some of the enslaved Africans from 'the Mandingoes \& Timmaneys' whilst others had been embarked at Port Loko, Rokelle and the Scarcies. ${ }^{158}$

During this early phase of naval intervention, there is evidence to indicate that some African leaders in nearby areas considered that the conduct of colonial officials was neither 'just' nor fair. In the course of his investigations into the cases of 167 'slaves seized in the colony' in 1809, Thomas Perronet Thompson recalled Almamy Dalu Muhammadu Dumbuya (Dala Modu) to Freetown to give evidence relating to the circumstances surrounding his expulsion from the

\footnotetext{
${ }^{155}$ See, for example, discussion surrounding five escaped slaves seeking protection in the colony in August 1793. Schwarz, Zachary Macaulay and the Development of the Sierra Leone Company, 1793-4: 1. Journal, June-October 1793, pp. 40-44; Substance of the Report, 1794, p. 125.

${ }^{156}$ Huntington Library, MY 419, Zachary Macaulay to Jean Babington, 9 February 1795.

${ }^{157}$ For a discussion of the release of recaptives at Sierra Leone, see Suzanne Schwarz, 'Reconstructing the Life Histories of Liberated Africans: Sierra Leone in the Early Nineteenth Century', History in Africa, 39, 2012, pp. 175-209.

${ }^{158}$ Ibid.
} 
colony by Thomas Ludlam in 1806. Dala Modu, son of Fendan Modu Dumbuya of Wonkafong, had been resident in Dalamodiya on the boundaries of the colony for over a decade, but was expelled by Ludlam following charges by Warwick Francis that he had sold a boy to the nearby slave fort of Bunce Island. ${ }^{159}$ In his later testimony to Thompson, Dala Modu explained how 'In palavers (councils) in the country among the Native Chiefs, I have heard complaints, that the people at Sierra Leone came \& pretended to have no Slave Trade, but if any of the slaves of the Natives ran away, they kept them \& made them work worse than Slaves'. He also made direct reference to the cases of the 'slaves seized in the colony' and was clearly incensed at the double-standards employed:

I heard on the Bullom shore that Slaves had been taken out of an American Sloop in Sierra Leone for some crime of the master, \& that the Slaves had been sold in the Sierra Leone Company's store. And when I heard this, I went to a Timmeney head-man named King George, \& said, "If these were any black people, I would fight them till they beat me or I beat them; for they have driven me from my houses because they said I sold slaves; \& now they are selling them themselves." ${ }^{160}$

Thompson, recalled swiftly to England following his criticisms of his abolitionist patrons, concluded that events surrounding the cases of the 'slaves seized in the colony' had caused 'the name of England to stink in the Nostrils of the Nations of Africa .... ${ }^{161}$

Governor Maxwell's policy of attacking slave ships seeking protection in the rivers as well as slave factories in areas outside his legal jurisdiction in the Rio Pongo in 1813 and 1814 was the subject of a formal complaint by Almamy Amara Touré, a headman of Moria. Mouser considers that this complaint no doubt reflected wider hostility towards the colony among headmen in the Rio Nunez and Rio Pongo. In March 1814, Amara complained to Maxwell that his actions were interrupting their commerce, and he reminded the Governor that such behaviour would provoke a hostile response. He also pointed out that 'You know this country belongs unto us the Natives of it. You are the "Stranger" ... we are the proprietors'. Amara stated that:

If you do not want to buy any Slaves please do let those people that want to buy them come unto us freely, \& do not take their Ships \& property away from them. If you do, take care of yourself. Don't think you will get any black man's thing in all this Country either to buy or to eat.

${ }^{159}$ Mouser, 'Alimaami Dalu Muhammadu Dumbuya: Trial of a Slave Trader'.

${ }^{160}$ Cited in Bruce L. Mouser, 'The Expulsion of Dalu Modu: A Muslim Trader in Anti-Slavery Freetown', in Alice Bellagamba, Sandra Greene and Martin Klein, eds., African Voices of Slavery and the Slave Trade, New York, 2012, pp. 334-41.

${ }^{161}$ University of Illinois, Chicago, Edward H. Columbine, Public Papers, Africa, 'Sentence Pronounced in the Court of Vice Admiralty at Sierra Leone, November $6^{\text {th }} 1809$ by Thomas Perronet Thompson, Judge of that Court, and Governor of the Colony, in the case of certain captur'd negroes, alledged to have been illegally sold at Freetown', transcript. 
He also pointed to the apparently shifting and contradictory policies of the colony in regard to trade, and highlighted how:

First White people came this country for trade palaver. We all were very glad of it, \& whatsoever they wanted we tried to get it, Bulls, fur, yams, oil, Slaves, Ivory etc. But to day White people come to take the country away from us $\&$ to make Slaves of us in return. Nor will they suffer any person to come near us except as they like. ${ }^{162}$

Later interceptions by naval commanders resulted in the diversion of ships that had embarked slaves much further afield in the Bight of Benin, the Bight of Biafra and West-Central Africa. As the recaptives were drawn from areas widely spread across the continent, they provided the basis for an enhanced knowledge of Africa and African languages. By the late 1840s Sigismund Wilhelm Koelle, a missionary with the Church Missionary Society (CMS), was able to treat Freetown as a laboratory for the study of African languages and he collected 'specimens of 200 African languages or dialects, all spoken in Sierra Leone, ranging in origin from Mozambique to Senegal', which were subsequently published in his Polyglotta Africana in $1854 .{ }^{163}$ The recaptives also provided a large population of people who could serve as interpreters and missionaries, and this facilitated exploration in other areas as in the 1841 Niger Expedition and the CMS Yoruba Mission from 1842 onwards.

\section{V}

Despite the loss of all the shareholder capital and the failure of its commercial objectives, Company ideas had a lasting influence. ${ }^{164}$ Their continuing influence can be traced in the work of the African Institution and subsequently in Thomas Fowell Buxton's influential book The African Slave Trade and its Remedy published in 1840. A quarter of shareholders in the African Institution were among the original shareholders in the Sierra Leone Company and leading lights of the Society for Missions to Africa and the East, including Josiah Pratt, were among subscribers to the new organization. The influence of ideas contained in Thomas Clarkson's report and Watt's journal to Timbo can be traced in a medallion designed by Zachary Macaulay and struck at Matthew Boulton's Soho Mint. This bronze medallion (Figure 5), which carried an Arabic inscription

162 Bruce L. Mouser, American Colony on the Rio Pongo. The War of 1812, the Slave Trade, and the Proposed Settlement of African Americans, 1810-1830, Trenton, NJ, 2013, pp. 63-80.

${ }^{163}$ Fyfe, History, p. 237. In 1863, Robert Clarke commented on how 'the negro population of Sierra Leone represents almost every tribe in West Africa', and he estimated that 'Fifty different languages are in use among the liberated Africans ...'. Clarke, 'Sketches of the Colony of Sierra Leone and its Inhabitants', p. 329.

${ }^{164}$ In the published report of 1808 , it was estimated that the value of the Company's property was just over $£ 11,000$. Substance of the Report Delivered by the Court of Directors of the Sierra Leone Company, to the General Court of Proprietors, on Thursday the $24^{\text {th }}$ of March, 1808, London, 1808, p. 15. 


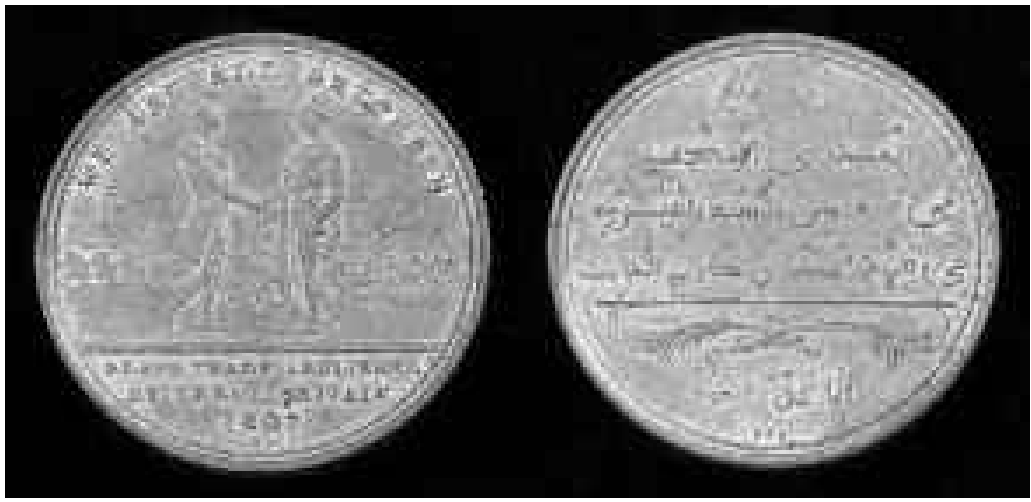

Figure 5. Medal Commemorating the Abolition of the Slave Trade, 1807. The translated inscription states 'Sale of Slaves prohibited in 1807, Christian era, in the reign of George the Third; verily we are all brothers'. FO653-1 and FO653-2. (c) National Maritime Museum, Greenwich, London, Michael Graham-Stewart Slavery Collection.

drawing attention to the abolition of the slave trade, was intended to deter Muslim traders from bringing slave caravans to sell at the coast. The obverse carries an image of an African in an upright stance shaking hands with a European, and the background scene of Africans dancing and tending the soil depicts the happy scenes that would follow from abolition. ${ }^{165}$

The prospect of sending missionaries to the Fuuta Jalon was raised again in 1841 by the local committee of the Church Missionary Society at Freetown. William Cooper Thomson, a Scottish linguist, was selected to undertake a visit to Timbo with the primary objective of opening a secure route 'into the interior ... that would join the commerce of Freetown to the gold fields at Bouré and to the existing commerce of the Niger River networks'. He also received instructions from the head of the local committee of missionaries at Freetown advising him that, although his visit should appear to be of a 'mercantile nature', he should investigate the possibilities of establishing Christian missions and teaching. ${ }^{166}$ The Reverend John Warburton instructed Thomson to investigate issues similar to those commented on by Watt in $1794 .{ }^{167} \mathrm{He}$ was advised, for example, that questions of interest to 'our Parent Committee $\&$ the friends of Missions', included 'To what extent does the Slave Trade prevail, \& is there any

\footnotetext{
${ }^{165}$ National Maritime Museum, Greenwich, (www.nmm.ac.uk/visit/exhibitions), 'Medal Commemorating the Abolition of the Slave Trade, 1807'.

${ }^{166}$ Bruce L. Mouser, The William Cooper Thomson Expedition to Timbo and the Cycle of Regime Change in Funta Jalon, West Africa, 1841 to 1844, draft book manuscript supplied in private correspondence, January 2014, pp. ix-x, 1-14.

${ }^{167}$ Fyfe, History, pp. 214, 222.
} 
indication of the probability of their leaving it for the sake of commerce $\&$ agriculture?'. The queries also included 'Whether there is any indication of their willingness or desire to receive a Missionary?' and 'What assistance will the King of the Foulahs render, in case he wants, \& the Society can send a Missionary?'168

One of Buxton's key proposals was the need to make 'the African ... our confederate in the suppression of the Slave Trade'. ${ }^{169}$ In this respect, Buxton's ideas can be traced back to strategies tested out by Macaulay and other Company employees in their travels in the 1790s. In formulating ideas for his book, Buxton extracted quotations from the Company report to shareholders in 1794, including the statement 'put an end to the trade \& Africa shall be required to give the produce of her land \& labour instead of the inhabitants in payment for the necessaries of life. ${ }^{170}$ Buxton was also in regular contact with Clarkson who offered to send him a copy of his 1791 report saying that 'I think you would be pleased to see it'. ${ }^{171}$ In reviving Company ideas, however, Buxton like Clarkson before him made a selective and largely uncritical use of the range of available evidence on Sierra Leone.

Clarkson's report had placed emphasis on how trade with the African interior would be facilitated by the extensive river network on the upper Guinea coast which would open up opportunities for the 'Christian Missionary to lay before unenlightened Nations the Gospel of Reconciliation and Peace..${ }^{172}$ His attempts in 1791 to describe the mechanisms of trade on the upper Guinea coast, an area noted for its extensive river networks, may have influenced his later use of an imaginary map of rivers and tributaries to represent the progress of the abolitionist cause (Figure 6). Although this engraving lacked any specific geographical context, it attempted to represent the flow and interchange of ideas in the development of transatlantic abolitionism prior to 1787. Names of individuals classified as abolitionists by Clarkson are linked to particular rivers and streams. As Marcus Wood points out, 'Clarkson's creation is not a map at all' but 'it attempts to recreate the memory of slavery through the new, lean, scientific conventions of late-eighteenth-century hydrography.'. ${ }^{173}$ In the 1820 s,

${ }^{168}$ Letter from the Reverend J. Warburton to William Cooper Thomson, 13 December 1841. Transcript of letter by Bruce L. Mouser. Source: Church Missionary Society, series CA1/O214 ('Papers, Letters, Reports [of] W. Cooper Thomson'), item 16, J. Warburton to W. C. Thomson, 13 December 1841. Also found at CMS, CA1/M10, p. 59ff.

${ }^{169}$ Thomas Fowell Buxton, The African Slave Trade and its Remedy, London, 1840, p. 8.

${ }^{170}$ Bodleian Library of Commonwealth and African Studies, Rhodes House, University of Oxford, Mss. Brit. Emp. s. 444, Papers of Thomas Fowell Buxton [hereafter RH, Buxton papers], vol. 36, pp. 307, 312, 315, 319

${ }^{171}$ RH, Buxton Papers, Clarkson to Buxton, 26 November 1838, vol. 3, pp. 143-51.

${ }^{172}$ BL, Sierra Leone, 'Letter Addressed to the Chairman of the Sierra Leone Company', f. 20r.

${ }^{173}$ The illustration includes no reference to abolitionists of African descent or the 'New World slave'. Marcus Wood, Blind Memory. Visual Representations of Slavery in England and America 1780-1865, Manchester, 2000, pp. 1-6; J.R. Oldfield, 'Chords of Freedom': Commemoration, Ritual and British Transatlantic Slavery, Manchester, 2007, p. 34. 
'A JUST AND HONOURABLE COMMERCE': ABOLITIONIST EXPERIMENTATION

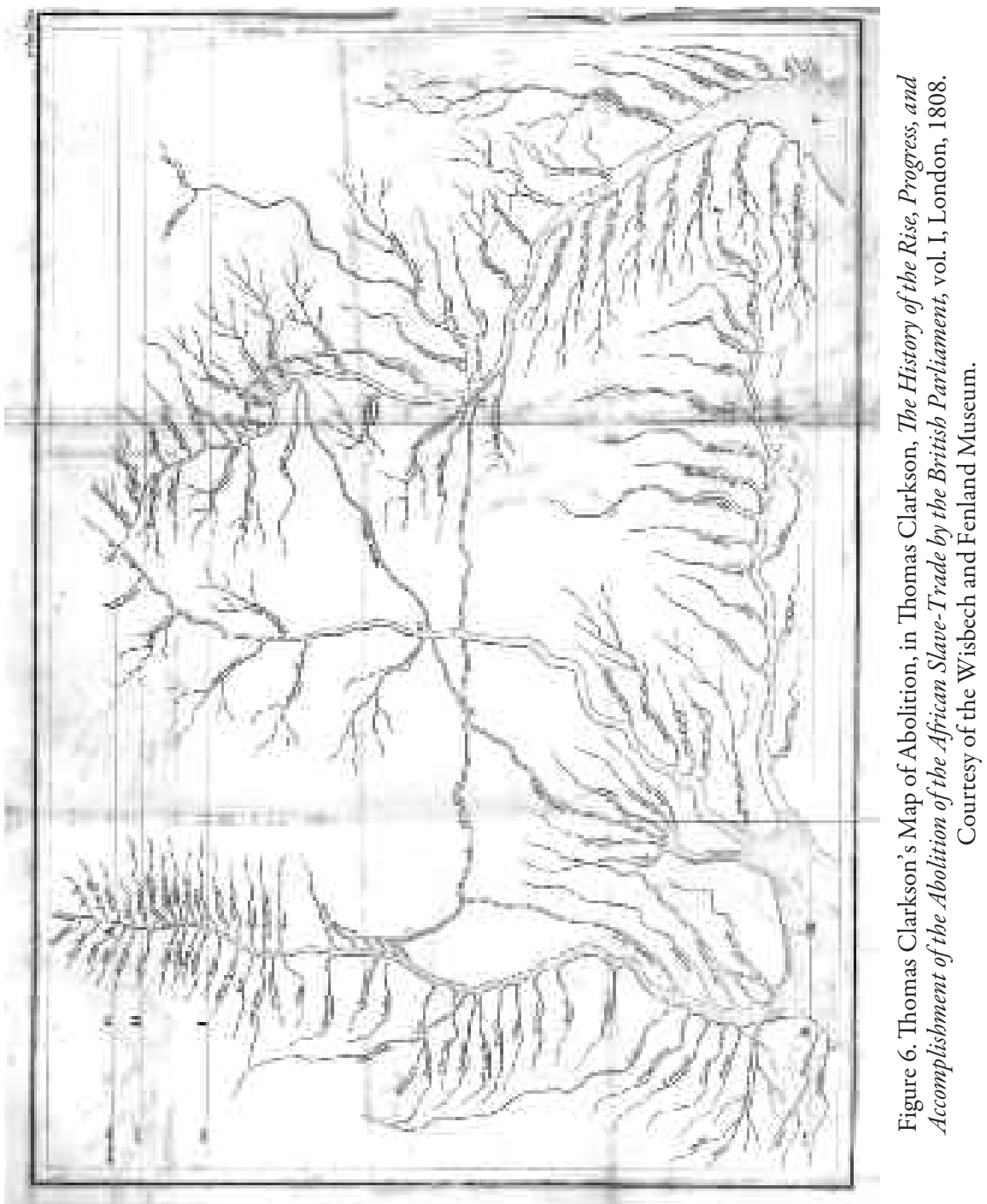


continued European interest in accumulating geographical knowledge on the African interior and tracing the course of the Niger River is reflected in the government-sponsored expedition of Dixon Denham and Hugh Clapperton. ${ }^{174}$ Conceptual links between exploration, navigable river systems, evangelization and commerce are later reflected in David Livingstone's Missionary Travels and Researches in South Africa in 1857. By arguing that the cultivation of raw materials in Africa would be the means by which 'we may not only put a stop to the slave-trade, but introduce the negro family into the body corporate of nations', Livingstone was articulating ideas that were not unique or original to him, but had long been central to abolitionist thought. ${ }^{175}$ Such ideas for developing 'a just and honourable commerce' were not new but had been central to Sierra Leone Company policy over half a century earlier.

(Plate 8)

${ }^{174}$ Curtin, Image of Africa, pp. 172-4. See also, E.W. Bovill, ed., Missions to the Niger. Volume II. The Bornu Mission 1822-25. Part 1, London, Hakluyt Society, 2nd ser., 128, 1966; E.W. Bovill, ed., Missions to the Niger. Volume III. The Bornu Mission 1822-25. Part 2, London, Hakluyt Society, 2nd ser., 129, 1966; E.W. Bovill, ed., Missions to the Niger. Volume IV. The Bornu Mission 182225. Part 3, London, Hakluyt Society, 2nd ser., 130, 1966; Jamie Bruce Lockhart and Paul E. Lovejoy, eds., Hugh Clapperton into the Interior of Africa. Records of the Second Expedition, 1825-1827 (Leiden, 2005).

${ }^{175}$ David Livingstone, Missionary Travels and Researches in South Africa, New York, 1858, p. 34; Law, Schwarz and Strickrodt, 'Introduction', pp. 5-6. 